\title{
Shepherding DNA ends: Rif1 protects telomeres and chromosome breaks
}

\author{
Gabriele A. Fontana ${ }^{1}$, Julia K. Reinert ${ }^{1,2}$, Nicolas H. Thomä ${ }^{1}$, Ulrich Rass ${ }^{1, *}$ \\ ${ }^{1}$ Friedrich Miescher Institute for Biomedical Research, Maulbeerstrasse 66, CH-4058 Basel, Switzerland. \\ ${ }^{2}$ University of Basel, Petersplatz 10, CH-4003 Basel, Switzerland. \\ * Corresponding Author: \\ Ulrich Rass, Tel: +41 6169617 30; orcid.org/0000-0001-9275-9062; E-mail: ulrich.rass@fmi.ch
}

ABSTRACT Cells have evolved conserved mechanisms to protect DNA ends, such as those at the termini of linear chromosomes, or those at DNA doublestrand breaks (DSBs). In eukaryotes, DNA ends at chromosomal termini are packaged into proteinaceous structures called telomeres. Telomeres protect chromosome ends from erosion, inadvertent activation of the cellular DNA damage response (DDR), and telomere fusion. In contrast, cells must respond to damage-induced DNA ends at DSBs by harnessing the DDR to restore chromosome integrity, avoiding genome instability and disease. Intriguingly, Rif1 (Rap1-interacting factor 1) has been implicated in telomere homeostasis as well as DSB repair. The protein was first identified in Saccharomyces cerevisiae as being part of the proteinaceous telosome. In mammals, RIF1 is not associated with intact telomeres, but was found at chromosome breaks, where RIF1 has emerged as a key mediator of pathway choice between the two evolutionary conserved DSB repair pathways of non-homologous endjoining (NHEJ) and homologous recombination (HR). While this functional dichotomy has long been a puzzle, recent findings link yeast Rif1 not only to telomeres, but also to DSB repair, and mechanistic parallels likely exist. In this review, we will provide an overview of the actions of Rif1 at DNA ends and explore how exclusion of end-processing factors might be the underlying principle allowing Rif1 to fulfill diverse biological roles at telomeres and chromosome breaks. doi: 10.15698/mic2018.07.639

Received originally: 05.03.2018,

in revised form: 08.05.2018,

Accepted 11.05.2018,

Published 17.05.2018.

Keywords: genome stability, telomere homeostasis, DNA double-strand break repair pathway choice, nonhomologous end-joining, DNA replication timing.
Abbreviations:
CDK - Cyclin-dependent kinase,
CST - Cdc13-Stn1-Ten1 complex,
CTD - C-terminal domain,
$D D K$ - Dbf4-dependent kinase,
$D D R$ - DNA damage response,
ds - double stranded,
$D S B$ - DNA double-strand break, $H R$ - Homologous recombination, MCM - Minichromosome maintenance complex,
MRN - MRE11-RAD50-NBS1
(mammalian complex),
MRX-Mre11-Rad50-Xrs2 (yeast
complex),
NHEJ - Non-homologous end-joining,
NTD - N-terminal domain,
PP1 - Protein phosphatase 1,
Rap1-Repressor/activator site-binding protein 1
RBM - Rap1-binding motif,
Rif1 - Rap1-interacting factor 1,
Rif2 - Rap1-interacting factor 2,
SIR - Silent information regulator, ss - single-stranded.

\section{RIF1 STRUCTURE AND FUNCTION}

Rif1 is a multifaceted genome caretaker involved in telomere homeostasis, DSB repair pathway choice, and the regulation of replication timing (Figure 1). Rif1 orthologs in yeast $[1,2]$ and higher eukaryotes [3-7] are divergent at the primary sequence level, but share key protein features. S. cerevisiae Rif1 consists of 1916 amino acids residues, has a molecular mass of $218 \mathrm{kDa}$, and contains four identifiable functional domains (Figure 2): 


\section{BOX 1: RIF1 AND PP1 PHOSPHATASES CONTROL REPLICATION TIMING IN EUKARYOTES}

In budding yeast $[10,16,17,20,21]$, fission yeast $[13,16]$, and mammalian cells $[14,15,18,22,23]$, downregulation of RIF1 leads to local alterations in the temporal pattern of replication initiation, consistent with a conserved mechanism through which Rif1 regulates DNA replication timing.

Origins of replication are licensed in late M and G1 phase of the cell cycle, and fire in a temporally controlled manner as cells progress through $S$ phase [24]. Origin firing requires assembly of the replicative helicase complex by association of Cdc45 (Cell division cycle 45) and GINS (Go-Ichi-Nii-San) proteins with the MCM (Minichromosome maintenance complex, comprised of Mcm2-7) catalytic core on DNA. This process is promoted by CDK and DDK (Dbf4-dependent kinase) activity. DDK-dependent phosphorylation of the unstructured Mcm4 N-terminal tail is essential for Cdc45-Mcm-GINS formation and initiation of DNA replication [25].

In budding yeast, this is attenuated by Rif1, which delivers protein phosphatase PP1 (Glc7) to origins of replication, leading to the dephosphorylation of Mcm4 and SId3 (Synthetically lethal with Dpb11-1), a factor required for Cdc45 recruitment [10, 16, 17] (Figure 1). Consistently, budding yeast Rif1 has been localized to the DNA replication origins that it regulates [21], and disruption of its RVxF/SILK PP1 interaction motif results in misregulated replication timing, as well as suppression of replication failure in cells with mutations in the DDK catalytic subunit $[10,16,17]$. While Rif1 acts in replication timing across the genome [20], telomere sequestration enhances its effect on late replicating subtelomeric DNA in budding yeast [21]. It remains to be seen whether DNA binding by the Rif1 $1_{\text {NTD }}$ [19] is involved in mediating direct interactions between Rif1 and origin DNA. Besides control over subtelomeric regions of the genome, Rif1restricted origin firing within the heavily transcribed rDNA appears of particular importance for genome stability in budding yeast [26].

In S. pombe, Rif1 controls origin firing in similar fashion with the Dis2 and Sds21 phosphatases [13, 16], and the Rif1-PP1 axis is also conserved in mammalian cells $[14,15,18,22,23]$. Besides attenuating origin firing, human Rif1 also promotes origin licensing by stabilizing the ORC1 subunit of the origin recognition complex in G1 [18]. In addition to direct control of origin licensing/firing, Rif1 orthologs in fission yeast [27, 28] and mammals [22] have been proposed to play roles in shaping nuclear architecture to facilitate the establishment of discrete, late-replicating chromatin domains. In fission yeast, this has been linked to the ability of Rif1 to bind G-quadruplex DNA, determined by chromatin immunoprecipitation sequencing (ChIP-seq) and in vitro DNA-binding assays [27]. Based on the ability of budding yeast Rif1 to oligomerize [29], it was proposed the interaction with multiple G-quadruplex structures could allow Rif1 to organize chromatin loops, enabling Rif1-PP1 to act not only at sites of direct DNA interaction, but over long distances [27]. This is in contrast to budding yeast, where G-quadruplex binding was not found [19], and Rif1 was detected in direct proximity of the replication origins it regulates [21]. Given previous difficulties in determining Rap1-independent genomic sites of Rif1 binding by ChIP, and the recent success of mapping Rif1 to origins by chromatin endogenous cleavage sequencing (ChEC-seq) in budding yeast [21], it would be interesting to apply ChEC-seq in the fission yeast and mammalian systems to elucidate common and distinct mechanisms of replication timing control.

(1) RVxF/SILK protein phosphatase 1 (PP1; Glycogen 7 (Glc7) in budding yeast) docking site [8]. This site contains short KSVAF (residues 114-118) and SILR (146-149) signature sequences [6], which conform to PP1-docking motifs of the RVxF-type (consensus sequence $[R / K] x[V / I /] x[F / W]$, where $x$ denotes any amino acid except large hydrophobic residues) and SILK-type ([G/S]IL[R/K]) [9] (Figure 2A). A second putative RVxF/SILK domain has been identified (residues 316-320 and 222-225) [10, 11]. While the position of the RVxF/SILK domains varies across organisms (Figure 3), yeast and mammalian Rif1 orthologs bind PP1, delivering phosphatase activity to origins of replication to exert control over origin firing and DNA replication timing (see Box 1 for details) [10, 12-18]. While there is currently no evidence for an involvement of PP1 binding in the function of Rif1 in promoting DSB repair [19], a recent report indicates that Rif1-dependent recruitment of Glc7 has a role in controlling telomere homeostasis [11].

(2) The Rif1 N-terminal domain (NTD). In budding yeast, this domain is preceded by the RVxF/SILK motif and starts after residue 150 (Figure 2A), whereas the NTD starts at the very N-terminus of RIF1 in vertebrates [6]. The crystal structure of Rif $1_{\text {NTD }}$ has recently been solved (residues 177-1283), showing that this domain assumes an elongated fold composed of 23 irregular $\alpha$-helical repeat units containing a mixture of two-helix HEAT (Huntingtin, elongation factor 3 , protein phosphatase $2 \mathrm{~A}$, Tor1)-like and three-helix armadillo-like modules [19]. Overall, Rif $1_{\text {NTD }}$ resembles the shape of a shepherd's crook, with the hook formed by the N-terminal end (residues 185-874; referred to as Rif $1_{\text {ноок }}$ ) (Figure 2B). Rif $1_{\text {ноок }}$ is the most evolutionary conserved part of Rif1 and corresponds to Pfam domain Rif1_N (PF12231; residues 241-649) [30] (Figure 3). A highaffinity DNA-binding site in budding yeast Rif1 was identified within the highly positively charged concave face of the HOOK domain. Rif $1_{\text {NTD }}$ was co-crystallized with DNA, showing that Rif1 $1_{\text {NTD }}$ assembles into a head-to-tail dimer such that each HOOK domain forms a DNA binding channel in the resulting figure-8-shaped conformation, and this arrangement was confirmed in solution (Figure $\mathbf{2 C}$ ). Rif $1_{\text {NTD }}$ binds DNA in a sequence-independent manner, and associates with double-stranded (ds) and single-stranded (ss) DNA with nanomolar affinity. Direct DNA binding was the first activity that could be ascribed to the NTD and has been linked to a range of Rif1 genome maintenance functions, including telomere homeostasis and DNA repair [19] (explained in more detail below). Recently, murine RIF1 Nterminal DNA binding has been reported [31].

(3) Rap1 (Repressor/activator site-binding protein 1)binding motif (RBM, residues 1752-1772). Rap1 binds the dsDNA $T_{1-3}$ repeats at budding yeast telomeres in a sequence-specific manner and recruits Rif1 into the telosome (Figure 4). This interaction is essential for Rif1 to maintain telomere homeostasis, and disruption of Rif $1_{R B M}$, which 


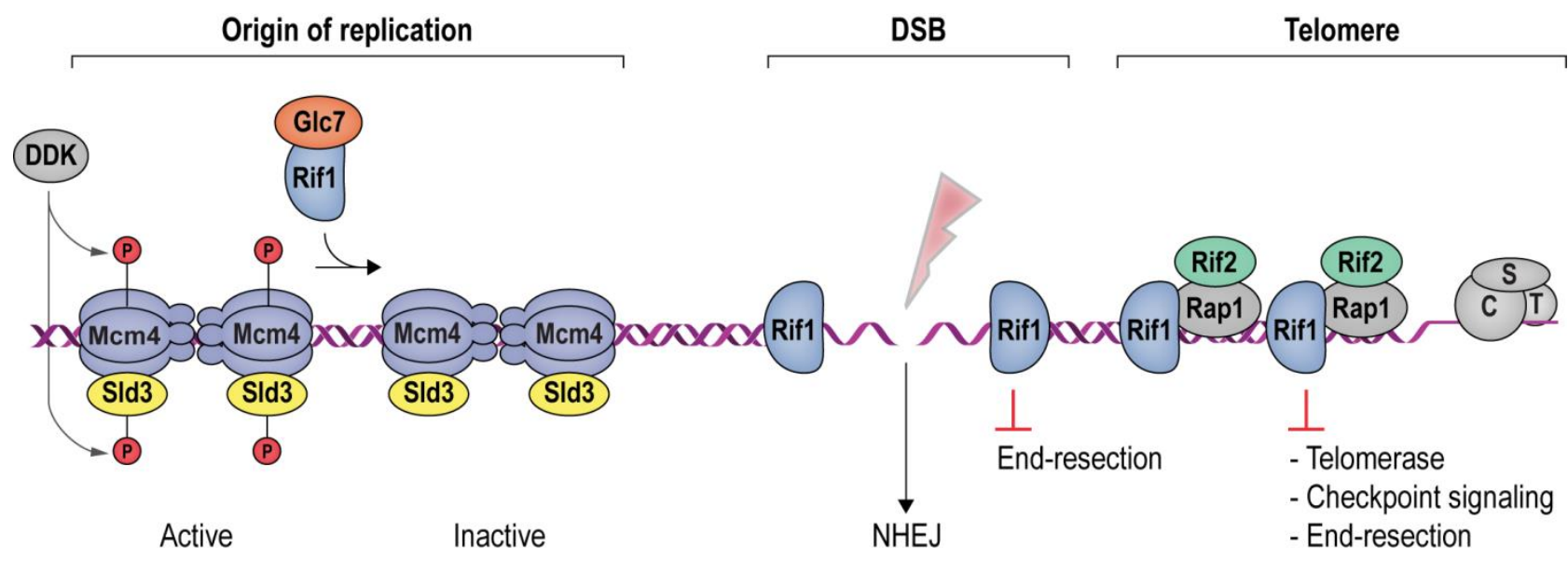

FIGURE 1: Rif1 is a multi-faceted genome maintenance factor. At origins of replication, Rif1 attenuates origin firing by recruiting PP1/Glc7, which reverses activating Mcm4 and SId3 phosphorylation mediated by DDK (see Box 1). At DSBs, Rif1 tightly encases the break ends, gating access of the end-resection machinery. As a result, DSB ends are stabilized, promoting their re-ligation by NHEJ. At budding yeast telomeres, Rif1 forms part of an interlinked telosome protein meshwork with Rap1 and Rif2, underpinning telomere architecture and function. In addition, direct Rif1-DNA interactions are required to counteract telomerase and inadvertent checkpoint activation at chromosome ends (see text for details). CST denotes the Cdc13-Stn1-Ten1 complex bound to ssDNA telomeric overhangs.

constitutes the main Rap1-binding epitope within Rif1, results in telomere dysfunction [29] (explained in more detail below). In fission yeast (Schizosaccharomyces pombe), Rif1 is recruited to telomeres by Taz1 (Telomereassociated in S. pombe 1) [2], and mammalian RIF1 is not part of the protective shelterin complex at telomeres [34]; this can explain why the Rif $1_{\mathrm{RBM}}$ motif is only found in Saccharomycetes.

(4) The Rif1 C-terminal domain (CTD). In budding yeast, crystal structure analysis has shown that Rif $1_{\text {CTD }}$ (residues 1857-1916) is a tetramerization module, as well as a secondary Rap1-binding interface [1, 29] (Figure 2A). In contrast to Rif $1_{R B M}$, the CTD is partially conserved from yeast to human. Specifically, the vertebrate CTD can be subdivided into three regions, CTD-I, II, and III (I: amino acids 2170 2246, II: 2274-2344, III: 2370-2446; residue numbers refer to human RIF1) (Figure 3), and CTD-II corresponds to Rif $1_{\text {CTD }}$ in budding yeast. CTD-I contains the canonical mammalian RVxF/SILK motif, while CTD-II was shown to have micromolar DNA-binding activity [31, 35, 36]. Moreover, mammalian RIF1 $1_{\text {CTD }}$ mediates an interaction with Bloom's syndrome helicase BLM, potentially linking RIF1 to replication stress-induced DNA damage repair [24].

\section{BUDDING YEAST RIF1 REGULATES TELOMERE HOMEO- STASIS}

\section{Rif1 underpins telomere architecture}

Budding yeast telomeres contain on average 300 base pairs of repetitive $\mathrm{TG}_{1-3} \mathrm{DNA}$, which is bound by 15-20 Rap1 molecules. Rap1 contains three domains including a BRCT (BRCA1 C-terminal) domain, the Rap1 C-terminal domain (RCT), and a tandem myb-type helix-turn-helix domain through which the protein engages dsDNA. The short (1215 nucleotides) telomeric ssDNA $\mathrm{TG}_{1-3} 3^{\prime}$ overhangs are bound by the CST complex, composed of $\mathrm{Cdc13}$ (Cell divi- sion cycle 13), Stn1 (Suppressor of cdc thirteen 1), and Ten1 (Telomeric pathways with Stn1). Rap1 and CST are essential genes and hypomorphs of these proteins lead to telomere dysfunction [37].

Rif1 interacts with the Rap $1_{R C T}$ through its RBM and CTD domains. The Rap1-binding epitope RBM is also found in Rif2 (Rap1-interacting factor 2) and the Sir (Silent information regulator) proteins, which are involved in transcriptional silencing $[1,29,38-40]$. The Rif1, Rif2, and Sir3 RBMs insert into a hydrophobic cleft within Rap $1_{R C T}$ in a mutually exclusive manner [29]. In addition, Rif1 and Rif2 possess secondary Rap $1_{\mathrm{RCT}}$-interaction modules: the Rif $1_{\mathrm{CTD}}$ (as described above), and a AAA+ (ATPase family associated with diverse cellular activities) domain within Rif2 [29]. Through its RBM and AAA+ domains, Rif2 can interlink adjacent Rap1 molecules, while Rif1, thanks to an extended linker between its RBM and CTD domains, can engage distant Rap1 proteins. Upon tetramerization, mediated by the CTD, Rif1 can bind up to four Rap1 molecules. Each individual Rap1-binding module within Rif1 and Rif2 is required for telosome stability, indicating the importance of the interconnected, Velcro-like Rap1-Rif1-Rif2 protein network for telomere architecture and function [29] (Figure 4).

At native telomeres, Rif1 and Rif2 regulate telomere length by inhibiting telomerase in cis [38, 43]. Similarly, when telomeric DNA sequences are inserted at a chromosome-internal locus that is then cleaved to expose a DNA end flanked by $\mathrm{TG}_{1-3}$ repeats, elongation of these telomeric sequences is attenuated by Rif1 and Rif2 [44, 45]. Thus, Rif1 contributes to the regulation of telomerase, an enzyme which adds simple sequence repeats to chromosome ends in order to counteract telomere shortening due to the end-replication problem and nucleolytic degradation [46]. It has been observed that telomerase preferentially associates with, and elongates, short telomeres, indicating that 
A

\section{S. cerevisiae Rif1}

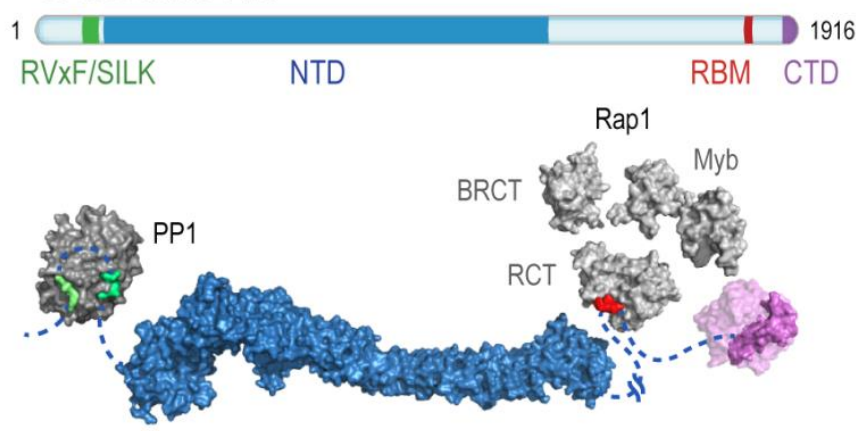

B
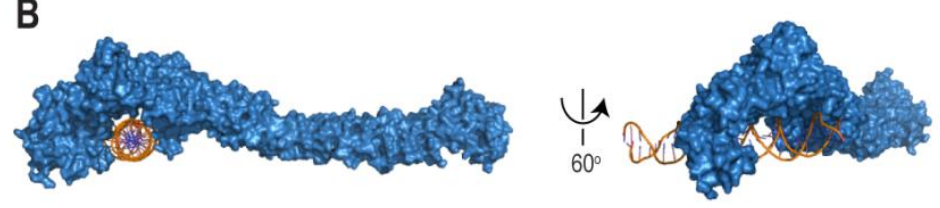

C

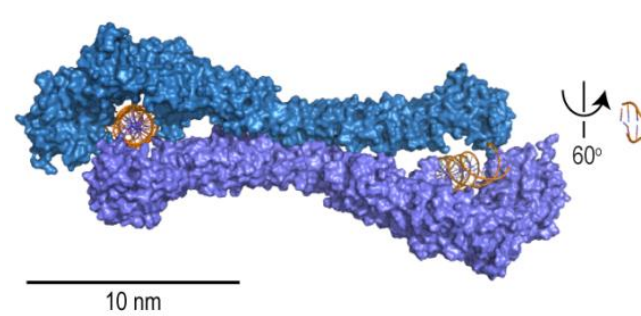

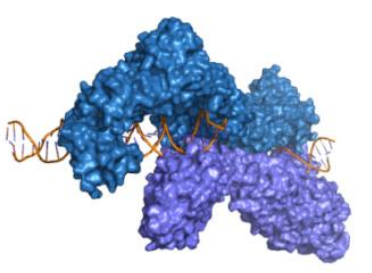

FIGURE 2: Rif1 domains and structural features. (A) Cartoon of S. cerevisiae Rif1 with structural representation of the indicated domains: RVxF/SILK PP1/GIc7 interacting motifs (green), NTD (N-terminal domain; blue), RBM (Rap1-binding motif; red) and CTD (Cterminal domain; purple). The RVxF (residues 115118) and SILK (residues 146-149) motifs are shown bound with protein phosphatase PP1 (dark grey), modelled on two available co-crystal structures (PDB: 4G9J for RVxF, serine/threonine-protein phosphatase PP1-alpha catalytic subunit, Homo sapiens [32] and PDB: 208A for SILK, serine/threonine-protein phosphatase PP1-gamma catalytic subunit, Rattus norvegicus [33]). A flexible linker connects the RVxF and SILK motifs with the NTD (residues 188-1766), which is shaped like a shepherd's crook (PDB: 5NVR [19]). The NTD connects via a 462 residue unstructured linker with RBM (residues 1752-1772). A co-crystal structure of RBM with the Rap1 C-terminal domain (RCT) is depicted (PDB: 4BJT). In addition, Rap1 contains BRCT and Myb domains (represented in light grey, Rap1 linker regions between structured domains not shown). CTD (C-terminal domain of Rif1, residues 1857-1916, PDB: 4BJS [29]) is a tetramerization domain, allowing oligomerization with other Rif1 molecules (as indicated in translucent purple). (B) The NTD of Rif1 in complex with dsDNA. (C) Rif1 $1_{\text {NTD }}$ bound with two distinct DNA molecules in the head-to-tail dimer conformation observed in Rif1-DNA co-crystals and in solution. Contacts with the DNA are made by the concave surface of the so-called HOOK domain at the $\mathrm{N}$-terminal end of the NTD [19]. long telomeres inhibit telomerase association more efficiently. The "protein counting" model postulates a negative feedback loop, by which the stochastic association of telomerase is increasingly suppressed when increasing amounts of Rap1, Rif1, and Rif2 are present [43, 47-51]. Conversely, reduced Rap1-Rif1-Rif2 occupancy at short telomeres increases the chance of telomere elongation, while Rap1 phosphorylation at short telomeres provides a mechanism to strengthen Rap1-Rif1 interactions and Rif1 occupancy at telomeres [52]. With telomere elongation coinciding with replication, there is also the possibility that the unimpeded progression of replication forks through shorter telomeres may favor telomerase association and telomere elongation [53-56]. Both of these models are compatible with the Velcro-like interactions of Rap1-Rif1Rif2, which are expected to lead to tighter telomere DNA packaging, and thus resistance to processing and/or replication factors, as telomere length (and with it Rap1-Rif1Rif2 occupancy at chromosome ends) increases [29].

\section{Rif1 inhibits telomere elongation by direct DNA binding}

While the Velcro-like interactions of the Rap1-Rif1-Rif2 protein network are essential in establishing telomere architecture, the recently discovered Rif $1_{\text {NTD }}$ DNA-binding activity proved to be equally important for telomere length regulation [19]. It has been demonstrated that disruption of the major Rap1-interaction epitope in Rif1 (the Rif $1_{\mathrm{RBM}}$ ) drastically reduces Rif1 occupancy at telomeres and results in telomere elongation [29]. In contrast, Rif1 $1_{\mathrm{NTD}}$ mutations, which reduced Rif1's ability to bind DNA, affected telomere association less severely, but had a much stronger effect on telomere elongation, phenocopying a RIF1 deletion [19]. These observations revealed a first Rap1-independent role for Rif1 in maintaining telomere homeostasis, showing that while Rap1 interactions are important to assemble Rif1 at chromosome effectively, the ability of Rif1 to bind DNA is crucial to gate access of telomerase.

\section{Rif1 suppresses checkpoint activation at telomeres}

In contrast to DSB ends, where the DDR initiates a network of signaling events that block cell-cycle progression and promote DNA repair [57], telomeric ends are protected from checkpoint activation by their capping complexes. Telomere uncapping in budding yeast by mutations in the CST complex exposes chromosome ends to the DDR, resulting in checkpoint activation [58-63]. Under these conditions, an attenuation of the DDR by Rif1 can be appreciated. For example, cells carrying the hypomorphic $c d c 13-1$ allele suffer progressive degradation of the 5 -terminated strand at telomeres [59], but a full-blown DDR is prevented by Rif1, such that cells are saved from terminal checkpoint arrest and survive [64]. Rif1's ability to suppress the lethality associated with $\mathrm{Cdc13}$ dysfunction is dependent on the ability of Rif $1_{\text {NTD }}$ to bind DNA, while depletion of Rif1 led to telomere hyperresection [19]. Consistently, Rif1 localizes to 


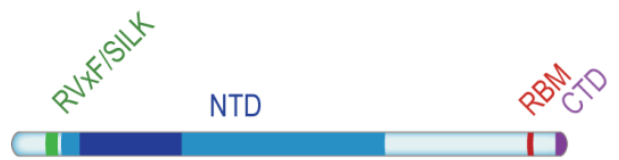

S. cerevisiae (1916)

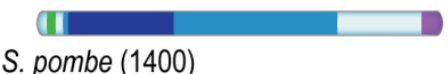

S. pombe $(1400)$

\section{H. sapiens (2472)}

FIGURE 3: Conserved domains of Rif1. Rif1 orthologs from budding yeast (S. cerevisiae), fission yeast (S. pombe) and human ( $H$. sapiens), aligned on the most conserved region of the protein (dark blue) present within the NTD, and corresponding to Pfam domain Rif1_N (residues 241-649 in S. cerevisiae, 108-471 in S. pombe, and 19-361 in H. sapiens). While the RVxF/SILK and NTD domains are found across organisms, RBM is only present in Saccharomycetes; the CTD domain is partially conserved from yeast to human (see text for details).

the ssDNA/dsDNA end-resection junction and reduces the accumulation of ssDNA-binding protein RPA (Replication protein $A$ ), dampening recruitment and activation of the apical checkpoint kinase Mec1 (Mitosis entry checkpoint 1; ATR in human) [65]. Analogously, Rif1 counteracts the DDR at a model of critically short telomeres, where a DSB is induced at a short, ectopic telomeric DNA repeat sequence $[45,66]$, and can facilitate checkpoint adaptation and cellcycle re-entry in the presence of DNA damage [67]. The anti-checkpoint function of Rif1 in the critically-short telomere model proved to be dependent on the ability of Rif $1_{\text {NTD }}$ to bind DNA [19]. These observations strongly indicate that direct Rif1-DNA interactions underpin Rif1's ability to dampen the DDR, potentially by contributing to the assembly of a proper telomere capping architecture and/or competitive exclusion of end-resection factors and checkpoint activators.

\section{RIF1 and telomeres in mammals}

RIF1 does not interact with the telomeric capping complex in mammalian cells, localizing to telomeres only if these are uncapped or critically short [4, 5, 34]. Binding at dysfunctional telomeres likely reflects the involvement of mammalian RIF1 in DSB repair rather than telomerespecific roles.

Nonetheless, there is an interesting link between RIF1 and telomere maintenance in mouse embryonic stem cells. In these cells, RIF1 is highly expressed [3] and helps restrict the expression of the ZSCAN4 (Zinc-finger and SCAN domain-containing 4) gene. ZSCAN4 encodes a protein that supports a recombination-dependent telomere-elongation mechanism active in mouse embryonic stem cells $[68,69]$. RIF1 binds to the ZSCAN4 promoter, where it interacts with components of the methyltransferase complex mediating histone H3 lysine 9 methylation (H3K9me). Thus, RIF1 facil- itates H3K9me and a transcriptionally silent chromatin state at the ZSCAN4 locus, suppressing hyperrecombination, telomere elongation, and chromosome aberrations [69].

\section{RIF1 IN DNA DOUBLE-STRAND BREAK REPAIR Two conserved pathways mediate DSB repair} DSB repair proceeds via NHEJ or HR [70, 71] (Figure 5). NHEJ is initiated by the association of the Ku heterodimer (Yku70 and Yku80) with DNA ends. Ku tightly encases DNA ends as a ring-like structure [72], forming a barrier to DNA degradation [73, 74]. Moreover, Ku serves as a scaffold for the recruitment of the core NHEJ machinery, comprised of the Dnl4-Lif1 (DNA ligase 4 and ligase-interacting factor 1) ligase complex and Nej1 (Non-homologous end-joining defective 1) [75-78]. When the Ku/Dnl4-Lif1/Nej1 complex is stably formed, the break ends are aligned and ligated. NHEJ can occur in all cell-cycle phases and is the preferred repair pathway in G1 and early S phase [70] (Figure 5).

DSB repair by HR requires a homologous repair template, which is usually provided by the unbroken sister chromatid $[79,80]$; thus, HR is mainly used for DSB repair during late $S$ and $G 2$ phase of the cell cycle [71]. In budding yeast, the first HR factor observed at DSBs is the MRX complex [81], constituted by Mre11 (Meiotic recombination 11), Rad50 (Radiation sensitive 50), and Xrs2 (X-ray sensitive 2) (MRE11, RAD50, and NBS1 (Nijmegen breakage syndrome gene 1) in mammals). Stimulated by phosphorylated Sae2 (Sporulation in the absence of Spo eleven 2; CtIP (CtBP-interacting protein) in mammals) and Ku, Mre11 introduces an endonucleolytic nick on the 5 '-terminated DNA strand, initiating DNA end-resection, which leads to the eviction of Ku [82-87]. Exonuclease Exo1 and the helicase/nuclease complex constituted by Sgs1 (Slow growth suppressor 1; BLM in mammals) and Dna2 (DNA synthesis defective 2) [88] then catalyze long-range $5^{\prime}$ to $3^{\prime}$ endresection $[89,90]$. In mammalian cells, MRE11 has been reported to cut both strands of the DNA in close proximity of the break, removing ends occluded by Ku and allowing EXO1 to engage for long-range end-resection [91]. The resection tracts are initially covered by RPA, which is then exchanged for the central recombinase Rad51 (Radiation sensitive 51) with the help of recombination mediator proteins. The resulting Rad51 nucleoprotein filament conducts homology search, seeking out a homologous template for DSB repair [92, 93] (Figure 5).

\section{DNA end-resection at DSBs determines repair pathway choice}

At DSBs, repair pathway choice is intricately linked with DNA end-resection. As described above, NHEJ requires limited, if any, end processing, and becomes inefficient when DNA ends are extensively resected [94]. In contrast, $\mathrm{HR}$ is dependent on end-resection and exposure of ssDNA tracts, which serve as substrate for the recombination machinery. End-resection is therefore a commitment to DSB repair by $\mathrm{HR}$, and in eukaryotes this commitment is linked 


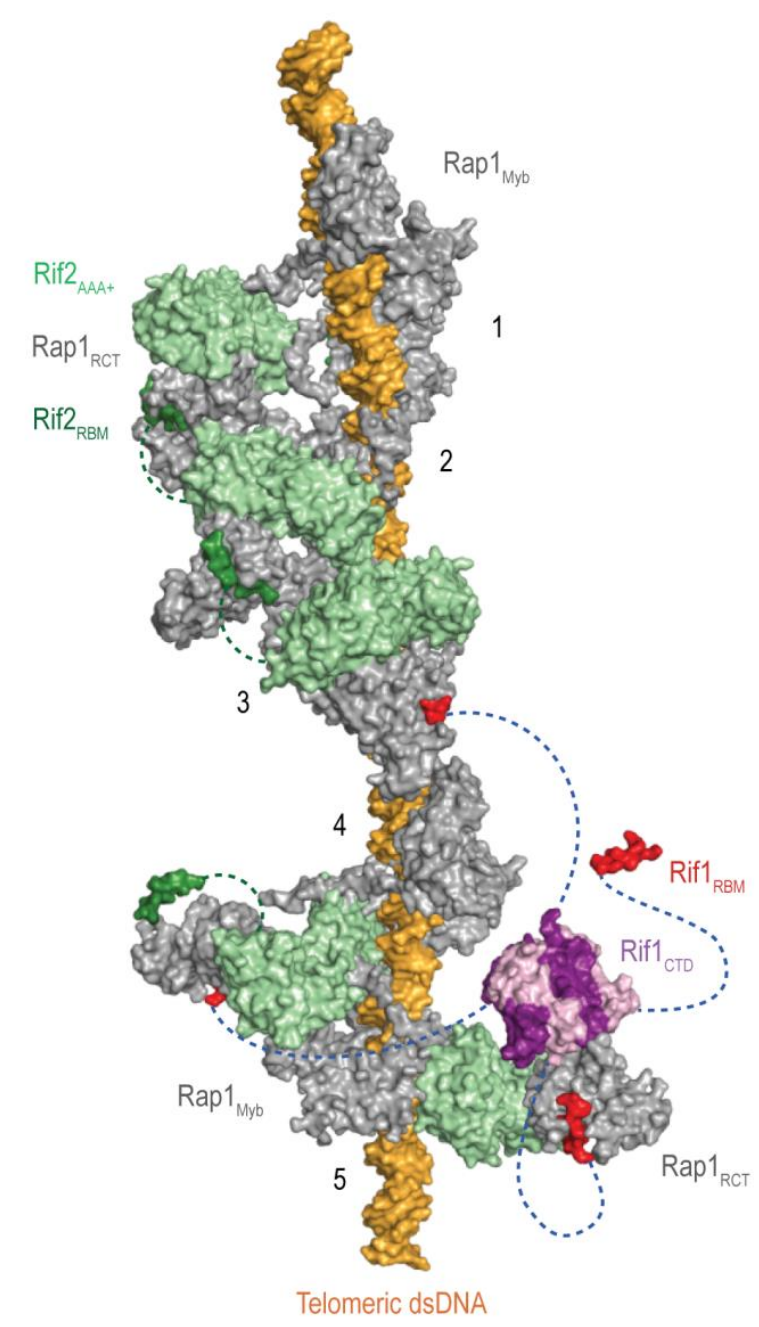

Figure 4: The Velcro-like protein network found at S. cerevisiae telomeres. Structural model illustrating the Rap1-Rif1-Rif2 interactions at dsDNA regions of budding yeast telomeres [29]. Rap1 (grey) engages DNA through its Myb domain (PDB: 1IGN [41]). Numbers 1 to 5 indicate Rap1-binding sites. Rif1 and Rif2 are recruited via the Rap1 $1_{R C T}$ domain (Rap1 C-terminal domain; linker regions not shown; PDB: 4BJ5 [29]; PDB: 3UKG [42]). In this example, each Rap1 $1_{R C T}$ is bound with Rif2 (PDB: 4BJ1 [29]) via the Rif2 $2_{\mathrm{AAA}}$ domain (light green). The Rif2 $2_{\mathrm{AAA}}$ domain is connected to the Rif2 ${ }_{\mathrm{RBM}}$ (dark green), a second Rap1 interaction epitope with similar affinity for Rap $1_{\mathrm{RCT}}$ [29]. A relatively short linker between Rif2 $2_{\mathrm{AAA}}$ and Rif2 $2_{\mathrm{RBM}}$ (green dotted line, maximal length of $42 \AA$ ) limits Rif2 to interlinking neighboring Rap1 molecules. At binding site 5, more complex Rap1-Rif1-Rif2 interactions are shown in exemplary fashion. The Rif $1_{\mathrm{RBM}}$ (red, PDB: $4 \mathrm{BJT}$ ) represents the major Rap1 interaction motif; the Rif1 $1_{\text {CTD }}$ (purple, PDB: 4BJS) plays an accessory role in Rap1 binding and serves as a tetramerization domain [29]. An extended flexible linker (blue dotted line) connects the RBM and CTD domains, allowing multimeric Rif1 to interlink up to four Rap1 units over long distances (maximal distance of $110 \AA$ ). The Rif $1_{\mathrm{RBM}}$ and Rif $2_{\mathrm{RBM}}$ bind Rap $1_{\mathrm{RCT}}$ in a mutually exclusive manner at the same hydrophobic cleft. In addition, RBM-bound Rap $1_{\mathrm{RCT}}$ can engage the Rif1 $1_{\mathrm{CTD}}$ or Rif2 $2_{\mathrm{AAA}+}$ domains. These multipoint interactions between interconnected Rap1, Rif1, and Rif2 stabilize the telosome and have been likened to a molecular Velcro [29]. The Rap1 $1_{\text {BRCT }}$ and Rif1 $1_{\text {NTD }}$ domains have been omitted for clarity. to the cell cycle and CDK (Cyclin-dependent kinase) activity [95]. In budding yeast, the sole CDK involved in cell-cycle control, Cdc28, regulates end-resection at DSBs [96, 97]. Cdc28 phosphorylates Sae2 [98], which stimulates Mre11 in nicking the $5^{\prime}$-terminated DNA strand, providing an entry site for the end-resection nucleases Exo1 and Dna2 [82, 84, 85]. Cdc28 also phosphorylates Dna2, promoting longrange end-resection [99], and the chromatin remodeler Fun30 (Function unknown now 30), which counteracts an end-protection activity exerted by DDR mediator Rad9 [100, 101]. As a result, end-resection and HR-mediated DSB repair are prevalent in late $S$ and $G 2 / M$ phases of the cell cycle, when CDK activity is high.

Similar CDK-dependent mechanisms promote endresection in mammalian cells [94]. Importantly, phosphorylation of mammalian Sae2 ortholog CtIP promotes its interaction with pro-resection factor BRCA1 (Breast cancer gene 1) [102-104]. RIF1, in conjunction with 53BP1 (p53binding protein 1) [105], counterbalances the BRCA1-CtIP axis of end-resection. The role of RIF1 in blocking endresection and promoting NHEJ in mammalian cells [106] is the subject of the next section.

An antagonism between 53BP1-RIF1 and BRCA1-CtIP mediates DSB repair pathway choice in mammalian cells RIF1 accumulates at DSBs in a manner dependent on apical DNA damage-checkpoint kinase ATM (Ataxia-telangiectasia mutated) and 53BP1 [4], a protein related to checkpoint mediator Rad9 in budding yeast [107] (Figure 6). ATM phosphorylates a cluster of $28 \mathrm{~N}$-terminal S/T-Q sites within 53BP1 to promote RIF1 binding [4, 108-117], but whether the interaction between RIF1 and 53BP1 is direct or involves as-yet unidentified accessory factors is currently not clear [118]. 53BP1 is a reader of multiple histone marks, allowing 53BP1-RIF1 recruitment to damaged chromatin surrounding DSBs in a highly controlled manner: (1) the tandem Tudor domain of 53BP1 interacts with dimethylated lysine 20 on histone 4 (H4K2Ome2) [119], and (2) the UDR (ubiquitylation-dependent recruitment) motif contacts mono-ubiquitylated lysine 15 on histone 2A (H2AK15ub) [120, 121]; (3) it has also been reported that the C-terminal tandem BRCT (BRCA1 C-terminal) domain of 53BP1 interacts with ATM-phosphorylated histone H2AX $(\gamma \mathrm{H} 2 \mathrm{AX})$ [122], however, as the BRCT domain appears to be dispensable for the recruitment of 53BP1 to damaged chromatin [111], the underlying functional relevance of this interaction remains to be elucidated. The H2AK15ub mark is specific to damaged chromatin and deposited by a ubiquitylation cascade involving RING-finger proteins RNF8 and RNF168 (Figure 6). H4K20me2 is a constitutive histone mark, which is diluted during replication due to new histone deposition in S phase. 53BP1 recruitment to sites of damage is therefore favored in G1 and less efficient in newly replicated chromatin in late $S$ phase or $G 2[123,124]$. Moreover, L3MBTL1 (Lethal 3 malignant brain tumor-like protein 1) [125] and KDM4A (Lysine specific demethylase 4A) [126] compete with 53BP1 for the binding of H4K2Ome2, while TIRR (Tudor-interacting repair regulatory protein) binds 53BP1, masking the interaction surface for 


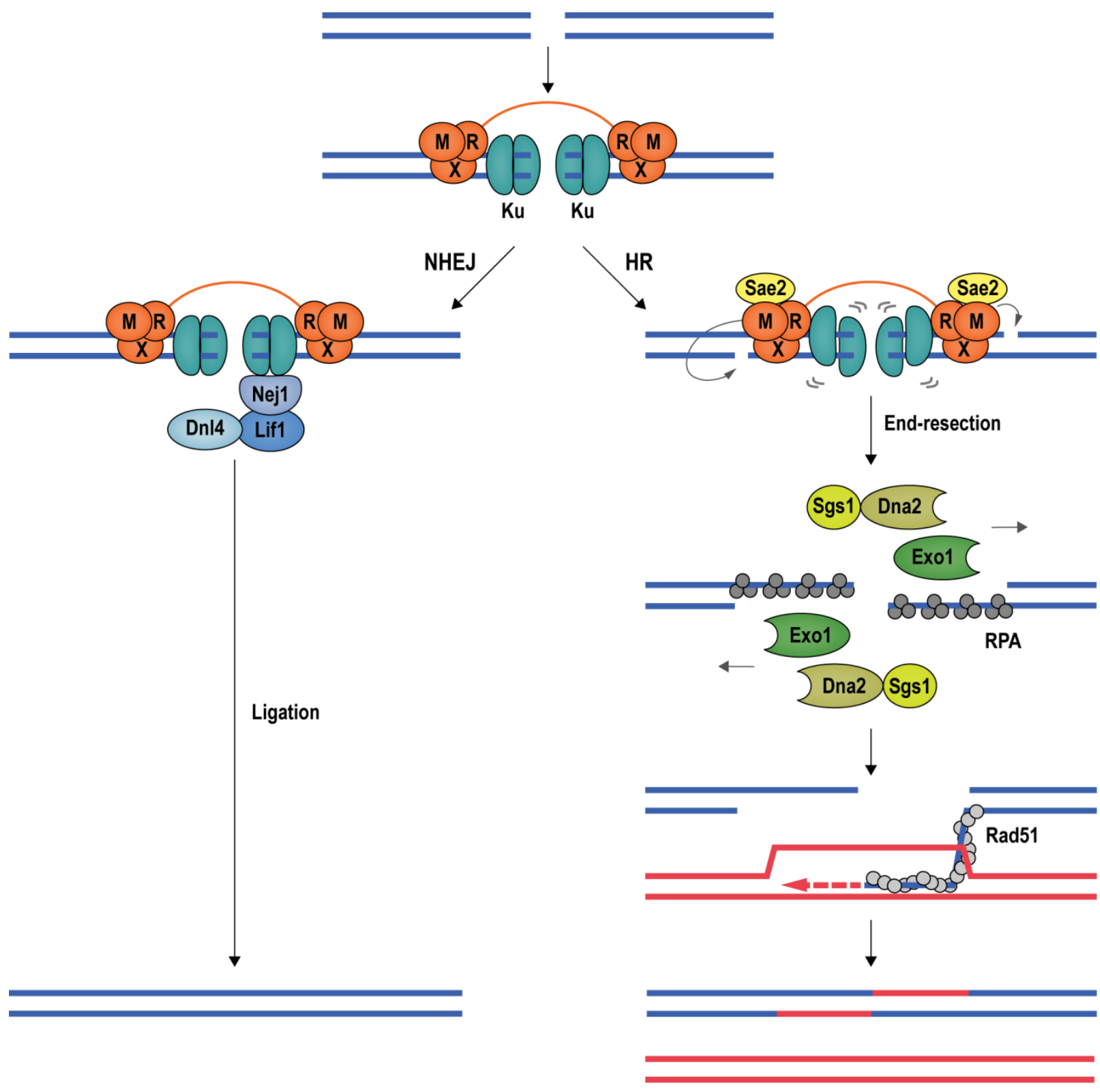

FIGURE 5: DSB repair by NHEJ and HR. The conserved mechanisms of DSB repair by NHEJ and HR are illustrated with budding yeast proteins. Left; Ku encircles DSB ends, recruiting the Lif1-Dnl4 and Nej1 ligase complex to promote NHEJ. Right; Stimulated by phosphorylated Sae2, Mre11 introduces nicks in the 5'-terminated DNA strands, destabilizing Ku. At the nicks, Exo1 and Sgs1-Dna2 initiate long-range endresection, exposing ssDNA, which is first coated by RPA, then by recombinase Rad51. The Rad51 nucleoprotein filament seeks out and invades a homologous donor sequence to initiate DNA repair synthesis. HR leads mostly to non-crossover products with a repair patch where new DNA has been synthesized.

methylated H4 [127]. Recruitment of 53BP1 to chromatin is further controlled by post-translational modifications deposited on 53BP1 itself. Thus, RNF168-dependent ubiquitylation [128], and PRMT1 (Protein arginine Nmethyltransferase 1)-dependent methylation [129] of 53BP1 favors its accumulation at sites of damage, while 53BP1 phosphorylation [130, 131] and acetylation [132] reduce the affinity of 53BP1 for H2AK15ub.

Observations showing that downregulation of 53BP1 induces ectopic BRCA1 recruitment to DSBs in G1, and that conversely, depletion of BRCA1 or CtIP leads to accumulation of 53BP1 at chromosomal breaks in G2, indicate that
53BP1 and BRCA1 compete for DSB binding [116]. CDKdependent phosphorylation of CtIP [133-135] favors the formation of a complex containing BRCA1, CtIP and MRN [103] at DSBs. BRCA1 and its partner BARD1 (BRCA1associated RING domain protein 1) form an E3 ubiquitin ligase, adding ubiquitin chains to $\mathrm{H} 2 \mathrm{~A}$. Ubiquitylated $\mathrm{H} 2 \mathrm{~A}$ attracts chromatin remodeler SMARCAD1 (SWI/SNFrelated matrix-associated actin-dependent regulator of chromatin subfamily A containing DEAD/H box1; Fun30 in budding yeast), which in turn evicts and repositions nucleosomes and 53BP1 at DSBs [136]. Ubiquitylation of RIF1, promoted by BRCA1 interactor UHRF1 (Ubiquitin-like, con- 
G1 and early S phase: low CDK activity

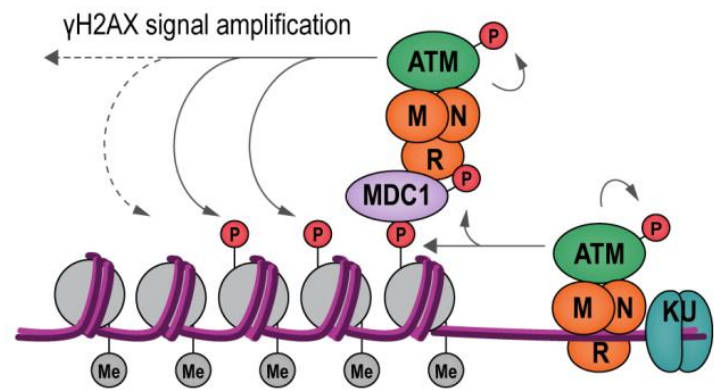

High H4K2Ome2
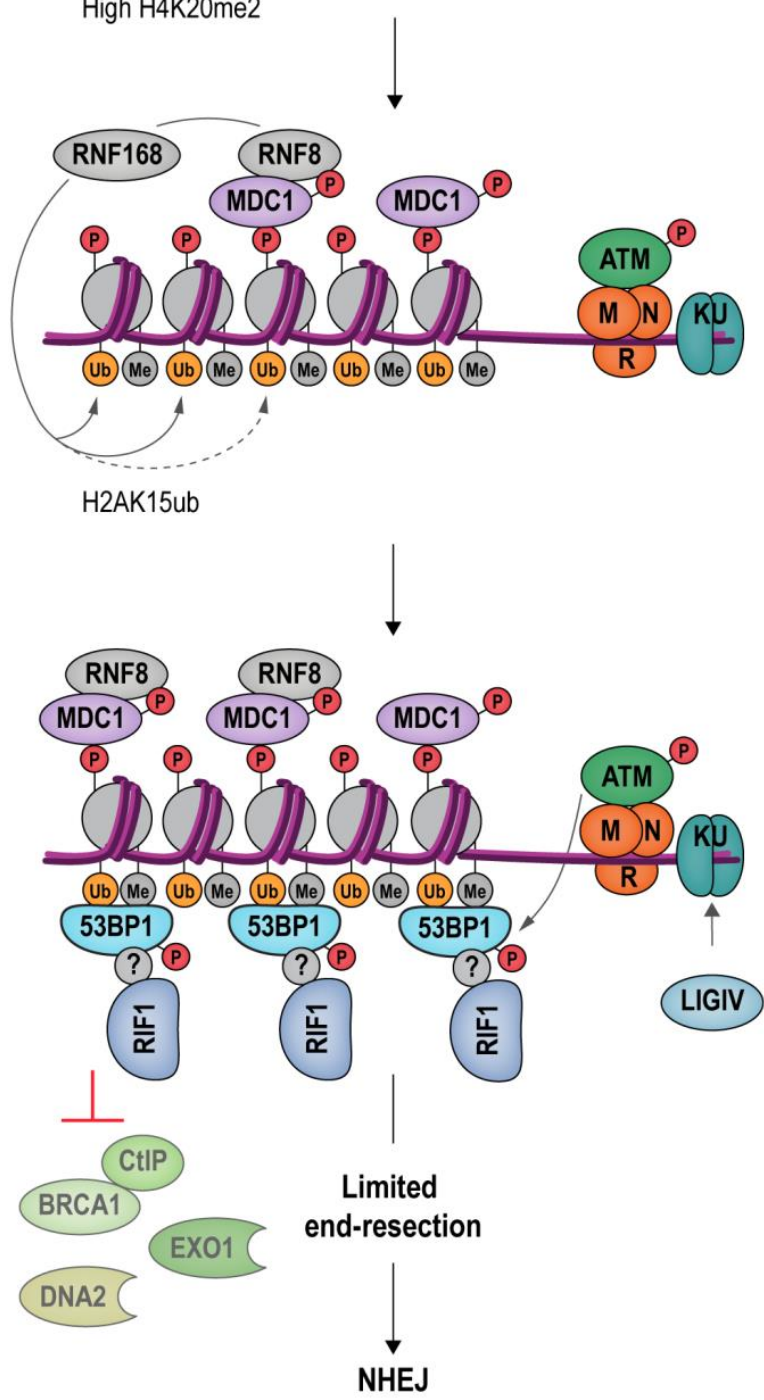

Late S and G2 phase: high CDK activity
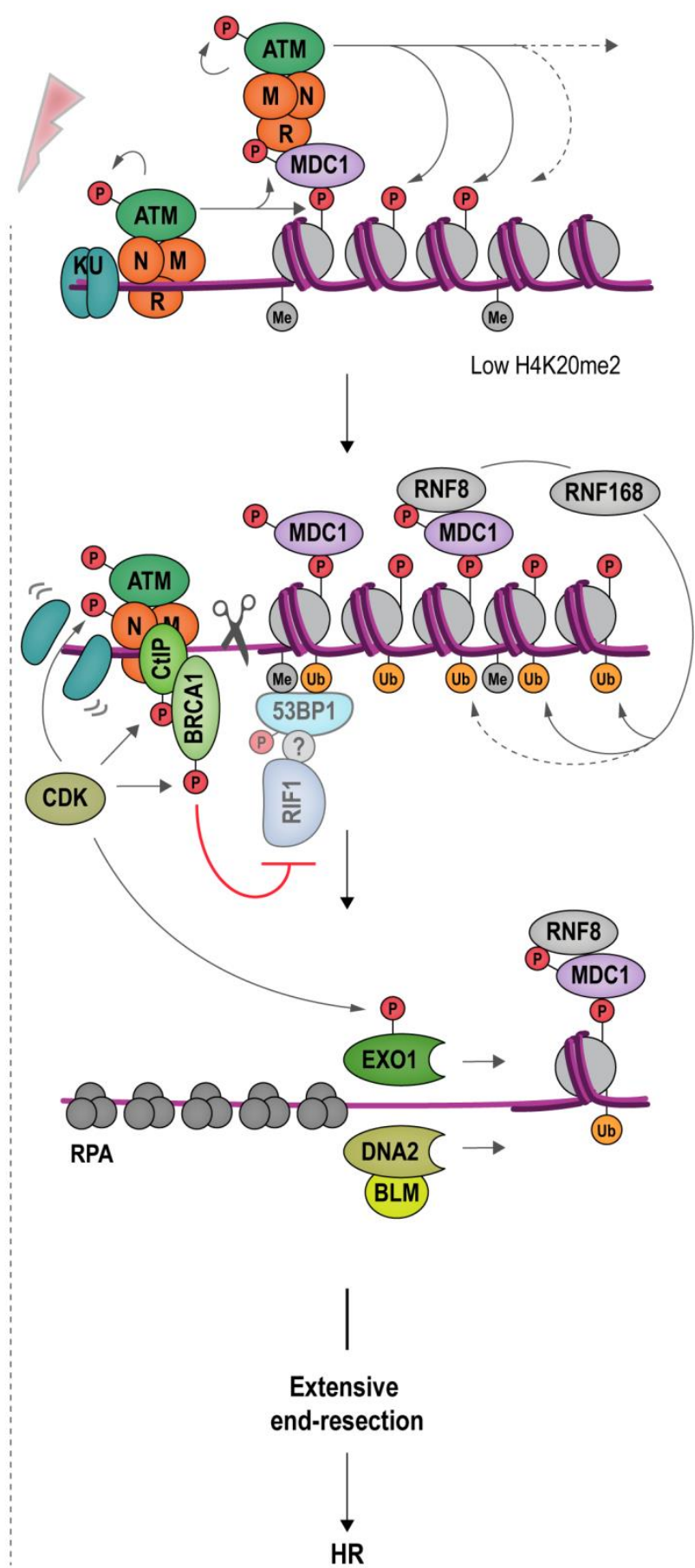

FIGURE 6: An antagonism between 53BP1-RIF1 and BRCA1-CtIP regulates DSB repair pathway choice in mammalian cells. DSB formation triggers a range of protein modifications that orchestrate the cellular response and DNA repair. MRN binds DSBs and recruits apical DDR kinase ATM, which phosphorylates H2AX ( $\gamma \mathrm{H} 2 \mathrm{AX}$ ). $\gamma \mathrm{H} 2 \mathrm{AX}$ attracts MDC1 (Mediator of DNA damage checkpoint protein 1), which becomes phosphorylated by ATM and binds additional MRN and ATM, providing a positive feedback loop for signal amplification. MDC1 also recruits RNF8, which cooperates with RNF168 to catalyze protein ubiquitylation at DSBs. H2AK15ub, together with H4K20me2, mediates binding of 53BP1 at DSBs. In its ATM-phosphorylated form, 53BP1 interacts with RIF1, although it remains to be determined whether this interaction is direct. The 53BP1-RIF1 complex blocks resection and inhibits BRCA1-CtIP, EXO1 and DNA2 through an as yet unidentified molecular mechanism. Attenuation of resection results in NHEJ repair in G1 and in early S phase (left). In late $\mathrm{S}$ and G2 phase, CDK activity rises and the H4K2Ome2 mark is diluted as a consequence of new histone deposition during DNA replication. CDK stimulates the endonucleolytic activity of the MRN complex, and the recruitment of BRCA1-CtIP to damaged chromatin, while 53BP1-RIF1 binding is diminished. CDK-phosphorylated EXO1 and DNA2-BLM promote long-range resection, generating 3'-ssDNA overhangs, the substrate for the HR-dependent DSB repair machinery (right). 
taining PHD and RING finger domains 1), is also involved in dissociating RIF1 from DSB ends [137]. Following removal of 53BP1 and RIF1, end-resection, catalyzed by EXO1 [138, 139] and DNA2-BLM [140-142] can take place, initiating HR repair.

While 53BP1 and RIF1 are epistatic in repressing endresection at DSBs $[113,117]$, it is not yet understood how 53BP1 and RIF1 cooperate to inhibit the end-resection machinery and promote NHEJ mechanistically. By analogy to budding yeast, where Rif1 participates in organizing higherorder structures at telomeres [29] (Figure 4), it has been speculated that 53BP1 and RIF1 might arrange DSBs into structures less accessible for resection [118]. At uncapped telomeres, resembling one-ended DSBs, RIF1's role in attenuating end-resection is supported by BLM [35] and MAD2L2 (Mitotic spindle assembly checkpoint protein MAD2B) [143], and these interactions could putatively play similar roles at chromosome breaks. Finally, given the interaction between RIF1 and PP1 (see Box 1), it is tempting to speculate that the dephosphorylation of DDR and/or resection factors may be involved in RIF1-dependent attenuation of end-resection [106].

\section{Rif1 and DSB repair pathway choice in budding yeast: Rif1 attenuates DNA end-resection by tightly encasing DNA ends}

The involvement of $S$. cerevisiae Rif1 in DSB repair has emerged only recently. A first indication that budding yeast Rif1 may localize to broken DNA came from studies focused on the telomeric roles of Rif1. In a model for critically short telomeres, where a DSB is generated proximal to a short telomeric repeat sequence, Rif1 accumulates in a Rap1-dependent manner. Surprisingly, Rif1 was observed at these telomeric breaks even when its C-terminal Rap1interaction modules (the Rif $1_{\mathrm{RBM}}$ and Rif $1_{\mathrm{CTD}}$ domains) were disrupted, which suggested a Rap1-independent mechanism of recruitment [29]. This was confirmed by findings of Rif1 targeting induced DSBs at different places in the budding yeast genome, and in a manner fully independent of telomeric DNA sequences [19, 67, 144].

In contrast to the mammalian system, a first analysis of budding yeast Rif1 at non-telomeric DSBs showed that cells deleted for RIF1 accumulated less SsDNA at distances greater than $\sim 2 \mathrm{~kb}$ from a break site in $\mathrm{G} 1$ phase of the cell cycle [144]. This correlated with increased binding of DNA damage checkpoint mediator Rad9, a protein known for its ability to function as a barrier to end-resection [145, 146]. It therefore appears that Rif1 may facilitate longer-range end-resection by limiting Rad9 recruitment under certain conditions. While this Rif1-Rad9 interplay has been shown to be important for deleterious intrachromosomal break repair, any impact on canonical DSB repair by HR or NHEJ remains unclear [144, 147].

Further insight into the interaction of Rif1 with DSBs resulted from the identification of the Rif $1_{\text {NTD }}$ DNA-binding site (Figure 2). In vitro, Rif $1_{\text {NTD }}$ binds dsDNA and ssDNA substrates in a sequence-independent manner, showing preference for 3'-tailed ssDNA-dsDNA junctions, a DNA structure similar to those found at telomeric ends and DSB ends. As mentioned above, direct DNA binding by the Rif1 $1_{\text {NTD }}$ was found to play critical in vivo roles by counteracting telomerase and the attenuation of end-resection at uncapped telomeres in budding yeast. Analogously, and mirroring the situation in mammalian systems, Rif $1_{\text {NTD }}$ also engages DSBs, attenuates end-resection, and promotes NHEJ [19]. In yeast strains harboring an inducible DSB that can only be repaired by NHEJ $[148,149]$, loss of Rif1 destabilized the break ends and reduced repair by $\sim 40 \%$. Endprotection and the promotion of NHEJ by Rif1 was dependent on the DNA-binding activity residing in the HOOK domain of Rif1 $1_{\mathrm{NTD}}$; in contrast, the Rap1 and PP1-binding modules are apparently not required [19]. These findings show that the role of Rif1 in modulating DSB repair pathway choice is evolutionary conserved, and that the yeast and mammalian Rif1 orthologs are functionally more similar than previously thought.

The structural and functional evidence in budding yeast strongly suggests that Rif $1_{\text {NTD }}$ promotes NHEJ by tightly encasing DNA ends in a way that sterically excludes the end-resection machinery. In human, the NTD is strictly required for recruitment of Rif1 to DSBs, while the Cterminal part of the protein contributes moderately [116]. Based on the evolutionary conservation of the Rif $1_{\text {NTD }}[6]$ and recent reports of DNA binding by the murine RIF1 [31], it is tempting to speculate that Rif1 may operate in DSB repair by gating access to DNA ends across organisms.

\section{Possible means of regulation of budding yeast Rif1 in DSB repair}

In mammalian cells, the actions of RIF1 in DSB repair pathway choice are dependent upon 53BP1 [113, 115-117]. A potential functional equivalent to 53BP1 in budding yeast is Rad9. Like 53BP1, Rad9 is a reader of histone marks, interacting with damaged chromatin through its Tudor and BRCT domains binding H3K79me $[150,151]$ and $\gamma \mathrm{H} 2 \mathrm{AX}$ $[152,153]$, respectively. So far, no functional or physical interactions between Rad9 and Rif1 analogous to the mammalian 53BP1-RIF1 axis have been reported. Quite to the contrary, Rif1 has been shown to prevent the accumulation of Rad9 at telomeres, inhibiting the $\operatorname{DDR}[65,66]$. As described above, a similar antagonism between Rif1 and Rad9 may operate at DSBs $[67,144]$. How yeast Rif1 is regulated in NHEJ is an interesting open question. HEAT repeats have frequently been linked with protein-protein interactions [154], raising the possibility that, in addition to

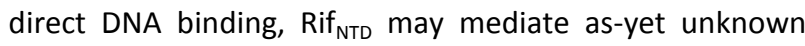
physical interactions regulating its functions in NHEJ.

In budding yeast, Rif1 has been seen in foci at the nuclear periphery, coinciding with the subnuclear position of telomeres [155-157]. Fission yeast Rif1 has been proposed to establish late-replicating domains by dictating specific chromatin architectures in proximity of the inner nuclear membrane [27] (see Box 1). Similarly, mouse RIF1 proved critical in linking nuclear spatial organization and replication timing, and based on the observation that RIF1 interacts with Lamin B1, this function may be exerted by physical interactions with the inner nuclear membrane [22] Given that nuclear compartments are important for DSB 
A

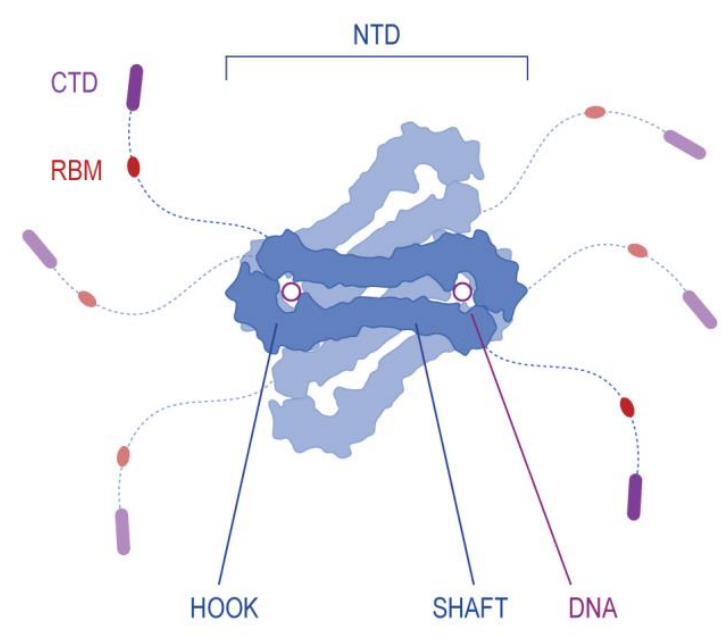

B

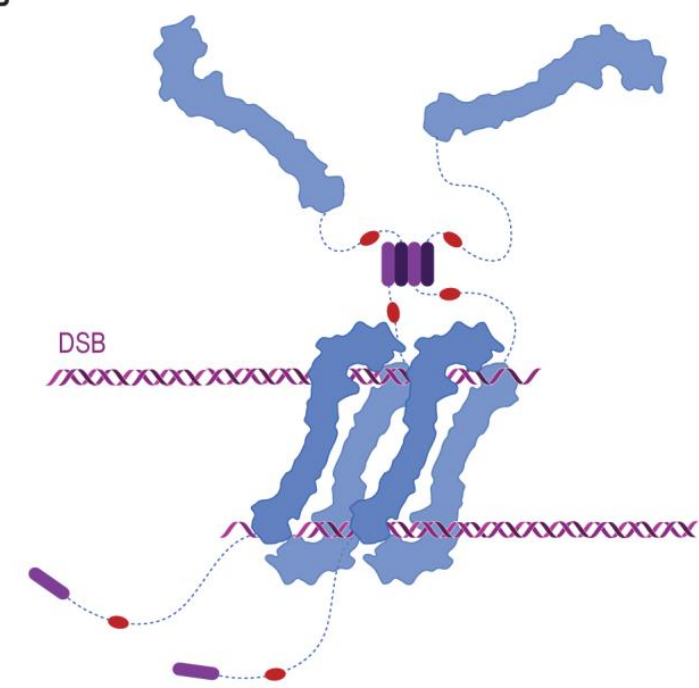

C

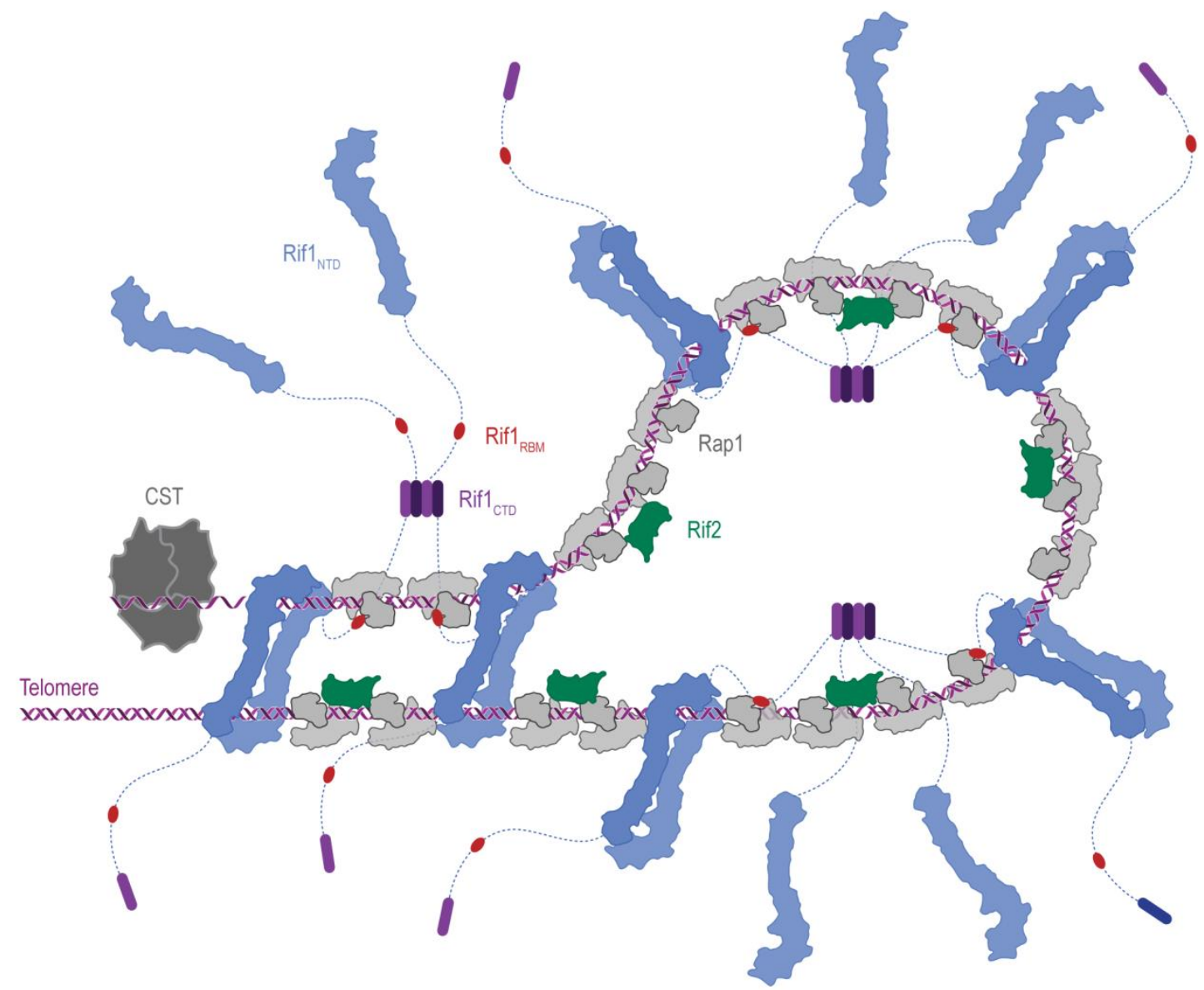

FIGURE 7: Ways in which Rif1 dimerization may promote DSB repair and shape telomere architecture. (A) Crystallographic model showing budding yeast Rif1 dimers bound to two DNA molecules [19]. The shepherd's crook-like Rif1 $1_{\mathrm{NTD}}$ (blue) comprises an N-terminal HOOK and a straight SHAFT region. Rif1 $1_{\mathrm{RBM}}$ (Rap1-binding domain, red) and Rif1 $1_{\mathrm{CTD}}$ (C-terminal tetramerization domain, purple) are connected to Rif1 $1_{\mathrm{NTD}}$ by unstructured linker regions (dotted lines). Rif1 $1_{\text {NTD }}$ has intrinsic DNA-binding activity and assembles on DNA as a figure 8-shaped, head-totail dimer. Multiple dimers may be organized around the same DNA molecules, forming a protein sheath, and restricting access of other proteins. (B) Speculative model of Rif1 dimers binding to the two ends of a DSB: tethering DSB ends in this way may promote re-ligation along the NHEJ pathway by keeping DSB ends in close proximity. (C) Schematic representation of the Velcro-like protein network formed by Rap1, Rif1 and Rif2 at yeast telomeres, taking DNA binding by Rif1 into account. Rap1 molecules (grey) directly bind dsDNA TG 1 -3 tracts, recruiting Rif1 and Rif2. Rif2 (green) interlinks adjacent Rap1 molecules, while Rif1, forming tetramers via its CTD, engages multiple Rap1 molecules through RBM epitopes. The NTD may allow Rif1 to directly engage telomeric DNA at sites not covered by Rap1. Fold-back structures could potentially be stabilized by Rif1-mediated DNA-bridging. 
repair $[158,159]$, it will be interesting to explore whether a nuclear-peripheral localization of Rif1 may be functionally involved in NHEJ.

\section{CONCLUSIONS AND FUTURE PERSPECTIVES}

Initially described as a telomeric protein in budding yeast [1], Rif1 is now recognized as a key genome maintenance factor that exists across eukaryotes. A growing body of evidence indicates that most of Rif1's diverse functions are evolutionary conserved. Studies in yeast $[10,13,16,17,20$, $21]$ and mammalian cells [14, 15, 18, 22, 23] have provided a detailed view of Rif1 in the regulation of replication timing by shared mechanisms involving control over origin firing and chromatin structure (Box 1). Pioneering work in mammalian cells has established RIF1 as a mediator of DSB repair pathway choice $[4,5,113,115-117]$. At DSBs, RIF1 promotes NHEJ by attenuating end-resection, although the mechanism of action in mammalian cells remains to be elucidated. The yeast model may prove informative in these efforts. Budding yeast Rif1 has long been regarded purely as a telomere maintenance factor, tethered to chromosome ends by DNA-binding protein Rap1 $[1,29]$. With recent studies linking budding yeast Rif1 to DSB repair, this view has changed $[19,67,144]$. Detailed structural analyses have revealed direct DNA binding by the conserved NTD of Rif1, which, in budding yeast at least, mediates functionally important interactions with chromosome ends and DSB ends alike [19]. The crook-shaped Rif $1_{\text {NTD }}$ encases DNA ends (Figure 2 and Figure 7A), gating access of processing factors. This provides an elegant, direct mechanism that allows Rif1 to control diverse biological processes including telomere elongation and end-resection Rif1 $1_{\text {NTD }}$-mediated DNA binding may be conserved in mammals [31], and it will be important to establish how generally the mechanistic insights from budding yeast apply to other eukaryotes.

Rif1 binds DNA in oligomeric form [19, 31]. In the Rif1DNA co-crystal, Rif $1_{\text {NTD }}$ is seen in a head-to-tail dimer configuration bound with two DNA molecules [19] (Figure 2C and Figure 7A). The significance of this intriguing arrangement remains to be elucidated in vivo, but it is tempting to speculate that multipoint DNA interactions may underpin Rif1 function. For example, tethering DSB ends, as seen in case of the MRX [160-166] and MRN complexes [167-170], could be involved in Rif1's role in promoting NHEJ (Figure 7B). At telomeres, higher-order chromatin structure is important for homeostasis. In mammalian cells, chromosome ends fold back on themselves and display a lariat-like structure (T-loops), generated by invasion of the $3^{\prime}$ ssDNA overhang into the dsDNA region of the telomere [171]. In hu- man, shelterin component TRF2 (Telomeric repeat-binding factor 2) is crucial in forming and maintaining T-loops [171, 172]. Similar fold-back structures exist in yeast, and in budding yeast Rif1 and Rif2 are implicated in their formation [173-177]. Although speculative at the moment, both Rif1 multimerization [29] and multi-point DNA binding [19], could promote the stability of higher-order telomere structures (Figure 7C), and by analogy may also support higher-order RIF1-53BP1 assemblies at repair sites.

In conclusion, Rif1 is emerging as a versatile and multifaceted genome maintenance protein involved in DNA replication timing, telomere maintenance, and the repair of chromosome breaks. It now appears that its cellular functions are largely conserved among eukaryotes. The way in which Rif1 is integrated into the telomere protective cap is unique to yeast. Yet, the finding that Rif1 utilizes an intrinsic DNA-binding activity within the conserved Rif1 $1_{\mathrm{NTD}}$ to regulate telomere length and end-resection at DSBs is compatible with the view that a conserved DNA repair protein has been "hijacked" and is moonlighting in telomere homeostasis [178]. The mechanistic parallels of direct DNA binding by Rif1 in DNA repair and telomere maintenance provide a satisfyingly unified view of Rif1 shepherding DNA ends to safeguard genome stability.

\section{ACKNOWLEDGMENTS}

The laboratories of N.H.T. and U.R. are supported by the Novartis Research Foundation. J.K.R. was supported by a Boehringer Ingelheim Fonds PhD fellowship. This work received funding from the European Research Council (ERC) under the European Union's Horizon 2020 research and innovation program (grant agreement no. 666068) and the Swiss National Science Foundation (Sinergia grant CRSII3_160734).

\section{CONFLICT OF INTEREST}

The authors declare that no competing interest exists.

\section{COPYRIGHT}

(C) 2018 Fontana et al. This is an open-access article released under the terms of the Creative Commons Attribution (CC BY) license, which allows the unrestricted use, distribution, and reproduction in any medium, provided the original author and source are acknowledged.

Please cite this article as: Gabriele A. Fontana, Julia K. Reinert, Nicolas H. Thomä, Ulrich Rass (2018). Shepherding DNA ends: Rif1 protects telomeres and chromosome breaks. Microbial Cell 5(7): 327-343. doi: 10.15698/mic2018.07.639

\section{REFERENCES}

1. Hardy CF, Sussel L, Shore D (1992). A RAP1-interacting protein involved in transcriptional silencing and telomere length regulation. Genes Dev 6(5): 801-814. doi: 10.1016/0168-9525(92)90388-K
2. Kanoh J, Ishikawa F (2001). spRap1 and spRif1, recruited to telomeres by Taz1, are essential for telomere function in fission yeast. Curr Biol 11(20): 1624-1630. doi: 10.1016/S0960-9822(01)00503-6

3. Adams IR, McLaren A (2004). Identification and characterisation of mRif1: a mouse telomere-associated protein highly expressed in germ 
cells and embryo-derived pluripotent stem cells. Dev Dyn 229(4): 733744. doi: 10.1002/dvdy.10471

4. Silverman J, Takai H, Buonomo SB, Eisenhaber F, de Lange $T$ (2004). Human Rif1, ortholog of a yeast telomeric protein, is regulated by ATM and 53BP1 and functions in the S-phase checkpoint. Genes Dev 18(17): 2108-2119. doi: 10.1101/gad.1216004

5. Xu L, Blackburn EH (2004). Human Rif1 protein binds aberrant telomeres and aligns along anaphase midzone microtubules. J Cell Biol 167(5): 819-830. doi: 10.1083/jcb.200408181

6. Sreesankar E, Senthilkumar R, Bharathi V, Mishra RK, Mishra K (2012). Functional diversification of yeast telomere associated protein, Rif1, in higher eukaryotes. BMC Genomics 13: 255. doi: 10.1186/1471-2164-13-255

7. Sreesankar E, Bharathi V, Mishra RK, Mishra K (2015). Drosophila Rif1 is an essential gene and controls late developmental events by direct interaction with PP1-87B. Sci Rep 5: 10679 . doi: 10.1038/srep10679

8. Hendrickx A, Beullens $M$, Ceulemans $H$, Den Abt T, Van Eynde $A$, Nicolaescu E, Lesage B, Bollen M (2009). Docking motif-guided mapping of the interactome of protein phosphatase-1. Chem Biol 16(4): 365-371. doi: 10.1016/j.chembiol.2009.02.012

9. Bollen M, Peti W, Ragusa MJ, Beullens M (2010). The extended PP1 toolkit: designed to create specificity. Trends Biochem Sci 35(8): 450458. doi: 10.1016/j.tibs.2010.03.002

10. Hiraga S, Alvino GM, Chang F, Lian HY, Sridhar A, Kubota T, Brewer BJ, Weinreich M, Raghuraman MK, Donaldson AD (2014). Rif1 controls DNA replication by directing protein phosphatase 1 to reverse Cdc7mediated phosphorylation of the MCM complex. Genes Dev 28(4): 372-383. doi: 10.1101/gad.231258.113

11. Kedziora S, Gali VK, Wilson RHC, Clark KRM, Nieduszynski CA, Hiraga SI, Donaldson AD (2018). Rif1 acts through Protein Phosphatase 1 but independent of replication timing to suppress telomere extension in budding yeast. Nucleic Acids Res 46(8): 3993-4003. doi: 10.1093/nar/gky132

12. Breitkreutz A, Choi H, Sharom JR, Boucher L, Neduva V, Larsen $B$, Lin ZY, Breitkreutz BJ, Stark C, Liu G, Ahn J, Dewar-Darch D, Reguly T, Tang X, Almeida R, Qin ZS, Pawson T, Gingras AC, Nesvizhskii Al, Tyers $M$ (2010). A global protein kinase and phosphatase interaction network in yeast. Science 328(5981): 1043-1046. doi: 10.1126/science. 1176495

13. Hayano $M$, Kanoh $Y$, Matsumoto $S$, Renard-Guillet $C$, Shirahige $K$, Masai $H$ (2012). Rif1 is a global regulator of timing of replication origin firing in fission yeast. Genes Dev 26(2): 137-150. doi: 10.1101/gad.178491.111

14. Cornacchia D, Dileep V, Quivy JP, Foti R, Tili F, Santarella-Mellwig R, Antony C, Almouzni G, Gilbert DM, Buonomo SB (2012). Mouse Rif1 is a key regulator of the replication-timing programme in mammalian cells. EMBO J 31(18): 3678-3690. doi: 10.1038/emboj.2012.214

15. Yamazaki S, Ishii A, Kanoh Y, Oda M, Nishito Y, Masai H (2012). Rif1 regulates the replication timing domains on the human genome. EMBO J 31(18): 3667-3677. doi: 10.1038/emboj.2012.180

16. Dave A, Cooley C, Garg M, Bianchi A (2014). Protein phosphatase 1 recruitment by Rif1 regulates DNA replication origin firing by counteracting DDK activity. Cell Rep 7(1): 53-61. doi: 10.1016/j.celrep.2014.02.019

17. Mattarocci S, Shyian M, Lemmens L, Damay P, Altintas DM, Shi T, Bartholomew CR, Thoma NH, Hardy CF, Shore D (2014). Rif1 controls DNA replication timing in yeast through the PP1 phosphatase Glc7. Cell Rep 7(1): 62-69. doi: 10.1016/j.celrep.2014.03.010
18. Hiraga SI, Ly T, Garzon J, Horejsi Z, Ohkubo YN, Endo A, Obuse C, Boulton SJ, Lamond AI, Donaldson AD (2017). Human RIF1 and protein phosphatase 1 stimulate DNA replication origin licensing but suppress origin activation. EMBO Rep 18(3): 403-419. doi 10.15252/embr.201641983

19. Mattarocci $S$, Reinert JK, Bunker RD, Fontana GA, Shi T, Klein $D$, Cavadini S, Faty M, Shyian M, Hafner L, Shore D, Thoma NH, Rass U (2017). Rif1 maintains telomeres and mediates DNA repair by encasing DNA ends. Nat Struct Mol Biol 24(7): 588-595. doi: 10.1038/nsmb.3420

20. Peace JM, Ter-Zakarian A, Aparicio OM (2014). Rif1 regulates initiation timing of late replication origins throughout the $\mathrm{S}$. cerevisiae genome. PLoS One 9(5): e98501. doi: 10.1371/journal.pone.0098501

21. Hafner L, Lezaja A, Zhang X, Lemmens L, Shyian M, Albert B, Follonier C, Nunes JM, Lopes M, Shore D, Mattarocci S (2018). Rif1 binding and control of chromosome-internal DNA replication origins is limited by telomere sequestration. Cell Rep 23(4): 983-992. doi: 10.1016/j.celrep.2018.03.113

22. Foti R, Gnan S, Cornacchia D, Dileep V, Bulut-Karslioglu A, Diehl S, Buness A, Klein FA, Huber W, Johnstone E, Loos R, Bertone P, Gilbert DM, Manke T, Jenuwein T, Buonomo SC (2016). Nuclear architecture organized by Rif1 underpins the replication-timing program. Mol Cell 61(2): 260-273. doi: 10.1016/j.molcel.2015.12.001

23. Alver RC, Chadha GS, Gillespie PJ, Blow JJ (2017). Reversal of DDKmediated MCM phosphorylation by Rif1-PP1 regulates replication initiation and replisome stability independently of ATR/Chk1. Cell Rep 18(10): 2508-2520. doi: 10.1016/j.celrep.2017.02.042

24. Bell SP, Labib K (2016). Chromosome Duplication in Saccharomyces cerevisiae. Genetics 203(3): 1027-1067. doi: 10.1534/genetics.115.186452

25. Sheu YJ, Stillman B (2010). The Dbf4-Cdc7 kinase promotes $S$ phase by alleviating an inhibitory activity in $\mathrm{Mcm} 4$. Nature 463(7277): 113-117. doi: 10.1038/nature08647

26. Shyian M, Mattarocci S, Albert B, Hafner L, Lezaja A, Costanzo M, Boone C, Shore D (2016). Budding yeast Rif1 controls genome integrity by inhibiting rDNA replication. PLoS Genet 12(11): e1006414. doi: 10.1371/journal.pgen.1006414

27. Kanoh $Y$, Matsumoto S, Fukatsu R, Kakusho N, Kono N, RenardGuillet C, Masuda K, lida K, Nagasawa K, Shirahige K, Masai H (2015). Rif1 binds to $G$ quadruplexes and suppresses replication over long distances. Nat Struct Mol Biol 22(11): 889-897. doi: 10.1038/nsmb.3102

28. Toteva $T$, Mason B, Kanoh $Y$, Brogger $P$, Green D, Verhein-Hansen J, Masai $H$, Thon $G$ (2017). Establishment of expression-state boundaries by Rif1 and Taz1 in fission yeast. Proc Natl Acad Sci USA 114(5): 1093-1098. doi: 10.1073/pnas.1614837114

29. Shi T, Bunker RD, Mattarocci S, Ribeyre C, Faty M, Gut H, Scrima A, Rass U, Rubin SM, Shore D, Thoma NH (2013). Rif1 and Rif2 shape telomere function and architecture through multivalent Rap1 interactions. Cell 153(6): 1340-1353. doi: 10.1016/j.cell.2013.05.007

30. Finn RD, Coggill P, Eberhardt RY, Eddy SR, Mistry J, Mitchell AL, Potter SC, Punta M, Qureshi M, Sangrador-Vegas A, Salazar GA, Tate J, Bateman A (2016). The Pfam protein families database: towards a more sustainable future. Nucleic Acids Res 44(D1): D279-D285. doi: 10.1093/nar/gkv1344

31. Moriyama K, Yoshizawa-Sugata N, Masai H (2018). Oligomer formation and G-quadruplex-binding by purified murine Rif1 protein, a key organizer of higher-order chromatin architecture. J Biol Chem 293(10): 3607-3624. doi: 10.1074/jbc.RA117.000446

32. Chatterjee J, Beullens M, Sukackaite R, Qian J, Lesage B, Hart DJ, Bollen M, Kohn M (2012). Development of a peptide that selectively 
activates protein phosphatase-1 in living cells. Angew Chem Int Ed Engl 51(40): 10054-10059. doi: 10.1002/anie.201204308

33. Hurley TD, Yang J, Zhang L, Goodwin KD, Zou Q, Cortese M, Dunker AK, DePaoli-Roach AA (2007). Structural basis for regulation of protein phosphatase 1 by inhibitor-2. J Biol Chem 282(39): 28874-28883. doi: 10.1074/jbc.M703472200

34. de Lange T (2005). Shelterin: the protein complex that shapes and safeguards human telomeres. Genes Dev 19(18): 2100-2110. doi: 10.1101/gad.1346005

35. Xu D, Muniandy P, Leo E, Yin J, Thangavel S, Shen X, li M, Agama K, Guo R, Fox D, 3rd, Meetei AR, Wilson L, Nguyen H, Weng NP, Brill SJ, Li $L$, Vindigni A, Pommier Y, Seidman M, Wang W (2010). Rif1 provides a new DNA-binding interface for the Bloom syndrome complex to maintain normal replication. EMBO J 29(18): 3140-3155. doi: 10.1038/emboj.2010.186

36. Sukackaite R, Jensen MR, Mas PJ, Blackledge M, Buonomo SB, Hart DJ (2014). Structural and biophysical characterization of murine Rif1 C terminus reveals high specificity for DNA cruciform structures. J Biol Chem 289(20): 13903-13911. doi: 10.1074/jbc.M114.557843

37. Wellinger RJ, Zakian VA (2012). Everything you ever wanted to know about Saccharomyces cerevisiae telomeres: beginning to end. Genetics 191(4): 1073-1105. doi: 10.1534/genetics.111.137851

38. Wotton D, Shore D (1997). A novel Rap1p-interacting factor, Rif2p, cooperates with Rif1p to regulate telomere length in Saccharomyces cerevisiae. Genes Dev 11(6): 748-760. doi: 10.1101/gad.11.6.748

39. Feeser EA, Wolberger C (2008). Structural and functional studies of the Rap1 C-terminus reveal novel separation-of-function mutants. J Mol Biol 380(3): 520-531. doi: 10.1016/j.jmb.2008.04.078

40. Chen Y, Rai R, Zhou ZR, Kanoh J, Ribeyre C, Yang Y, Zheng H, Damay $P$, Wang F, Tsujii H, Hiraoka $Y$, Shore D, Hu HY, Chang S, Lei M (2011). A conserved motif within RAP1 has diversified roles in telomere protection and regulation in different organisms. Nat Struct Mol Biol 18(2): 213-221. doi: 10.1038/nsmb.1974

41. Konig P, Giraldo R, Chapman L, Rhodes D (1996). The crystal structure of the DNA-binding domain of yeast RAP1 in complex with telomeric DNA. Cell 85(1): 125-136. doi: 10.1016/S0092-8674(00)81088-0

42. Matot B, Le Bihan YV, Lescasse R, Perez J, Miron S, David G, Castaing B, Weber P, Raynal B, Zinn-Justin S, Gasparini S, Le Du MH (2012). The orientation of the C-terminal domain of the Saccharomyces cerevisiae Rap1 protein is determined by its binding to DNA. Nucleic Acids Res 40(7): 3197-3207. doi: 10.1093/nar/gkr1166

43. Teixeira MT, Arneric M, Sperisen $P$, Lingner J (2004). Telomere length homeostasis is achieved via a switch between telomeraseextendible and non-extendible states. Cell 117(3): 323-335. doi: 10.1016/S0092-8674(04)00334-4

44. Negrini S, Ribaud V, Bianchi A, Shore D (2007). DNA breaks are masked by multiple Rap1 binding in yeast: implications for telomere capping and telomerase regulation. Genes Dev 21(3): 292-302. doi: 10.1101/gad.400907

45. Hirano $Y$, Fukunaga $K$, Sugimoto $K$ (2009). Rif1 and Rif2 inhibit localization of Tel1 to DNA ends. Mol Cell 33(3): 312-322. doi: 10.1016/j.molcel.2008.12.027

46. Hug N, Lingner J (2006). Telomere length homeostasis. Chromosoma 115(6): 413-425. doi: 10.1007/s00412-006-0067-3

47. Marcand S, Gilson E, Shore D (1997). A protein-counting mechanism for telomere length regulation in yeast. Science 275(5302): 986990. doi: 10.1126/science.275.5302.986

48. Marcand S, Brevet V, Gilson E (1999). Progressive cis-inhibition of telomerase upon telomere elongation. EMBO J 18(12): 3509-3519. doi: 10.1093/emboj/18.12.3509
49. Sabourin M, Tuzon CT, Zakian VA (2007). Telomerase and Tel1p preferentially associate with short telomeres in S. cerevisiae. Mol Cell 27(4): 550-561. doi: 10.1016/j.molcel.2007.07.016

50. McGee JS, Phillips JA, Chan A, Sabourin M, Paeschke K, Zakian VA (2010). Reduced Rif2 and lack of Mec1 target short telomeres for elongation rather than double-strand break repair. Nat Struct Mol Biol 17(12): 1438-1445. doi: 10.1038/nsmb.1947

51. Bianchi A, Shore D (2007). Increased association of telomerase with short telomeres in yeast. Genes Dev 21(14): 1726-1730. doi: $10.1101 /$ gad. 438907

52. Yang CW, Tseng SF, Yu CJ, Chung CY, Chang CY, Pobiega S, Teng SC (2017). Telomere shortening triggers a feedback loop to enhance end protection. Nucleic Acids Res 45(14): 8314-8328. doi: 10.1093/nar/gkx503

53. Dionne I, Wellinger RJ (1998). Processing of telomeric DNA ends requires the passage of a replication fork. Nucleic Acids Res 26(23): 5365-5371. doi: 10.1093/nar/26.23.5365

54. Marcand S, Brevet V, Mann C, Gilson E (2000). Cell cycle restriction of telomere elongation. Curr Biol 10(8): 487-490. PMID: 10801419

55. Bianchi A, Shore D (2007). Early replication of short telomeres in budding yeast. Cell 128(6): 1051-1062. doi: 10.1016/j.cell.2007.01.041

56. Greider CW (2016). Regulating telomere length from the inside out: the replication fork model. Genes Dev 30(13): 1483-1491. doi: 10.1101/gad.280578.116

57. Hustedt N, Gasser SM, Shimada K (2013). Replication checkpoint: tuning and coordination of replication forks in $\mathrm{S}$ phase. Genes (Basel) 4(3): 388-434. doi: 10.3390/genes4030388

58. Weinert TA, Kiser GL, Hartwell LH (1994). Mitotic checkpoint genes in budding yeast and the dependence of mitosis on DNA replication and repair. Genes Dev 8(6): 652-665. doi: 10.1101/gad.8.6.652

59. Garvik B, Carson M, Hartwell L (1995). Single-stranded DNA arising at telomeres in cdc13 mutants may constitute a specific signal for the RAD9 checkpoint. Mol Cell Biol 15(11): 6128-6138. doi: 10.1128/MCB.15.11.6128

60. Lydall D, Weinert T (1995). Yeast checkpoint genes in DNA damage processing: implications for repair and arrest. Science 270(5241): 1488-1491. doi: 10.1126/science.270.5241.1488

61. Grandin N, Reed SI, Charbonneau M (1997). Stn1, a new Saccharomyces cerevisiae protein, is implicated in telomere size regulation in association with Cdc13. Genes Dev 11(4): 512-527. doi: 10.1101/gad.11.4.512

62. Vodenicharov MD, Wellinger RJ (2006). DNA degradation at unprotected telomeres in yeast is regulated by the CDK1 $(\mathrm{Cdc} 28 / \mathrm{Clb})$ cell-cycle kinase. Mol Cell 24(1): 127-137. doi 10.1016/j.molcel.2006.07.035

63. Xu L, Petreaca RC, Gasparyan HJ, Vu S, Nugent Cl (2009). TEN1 is essential for CDC13-mediated telomere capping. Genetics 183(3): 793-810. doi: 10.1534/genetics.109.108894

64. Anbalagan S, Bonetti D, Lucchini G, Longhese MP (2011). Rif1 supports the function of the CST complex in yeast telomere capping. PLoS Genet 7(3): e1002024. doi: 10.1371/journal.pgen.1002024

65. Xue $Y$, Rushton MD, Maringele $L$ (2011). A novel checkpoint and RPA inhibitory pathway regulated by Rif1. PLoS Genet 7(12): e1002417. doi: 10.1371/journal.pgen.1002417

66. Ribeyre C, Shore D (2012). Anticheckpoint pathways at telomeres in yeast. Nat Struct Mol Biol 19(3): 307-313. doi: 10.1038/nsmb. 2225 
67. Xue Y, Marvin ME, Ivanova IG, Lydall D, Louis EJ, Maringele L (2016). Rif1 and Exo1 regulate the genomic instability following telomere losses. Aging Cell 15(3): 553-562. doi: 10.1111/acel.12466

68. Zalzman M, Falco G, Sharova LV, Nishiyama A, Thomas M, Lee SL, Stagg CA, Hoang HG, Yang HT, Indig FE, Wersto RP, Ko MS (2010). Zscan4 regulates telomere elongation and genomic stability in ES cells. Nature 464(7290): 858-863. doi: 10.1038/nature08882

69. Dan J, Liu Y, Liu N, Chiourea M, Okuka M, Wu T, Ye X, Mou C, Wang L, Wang L, Yin Y, Yuan J, Zuo B, Wang F, Li Z, Pan X, Yin Z, Chen L, Keefe DL, Gagos S, Xiao A, Liu L (2014). Rif1 maintains telomere length homeostasis of ESCs by mediating heterochromatin silencing. Dev Cell 29(1): 7-19. doi: 10.1016/j.devcel.2014.03.004

70. Daley JM, Palmbos PL, Wu D, Wilson TE (2005). Nonhomologous end joining in yeast. Annu Rev Genet 39: 431-451. doi: 10.1146/annurev.genet.39.073003.113340

71. Haber JE (2016). A life investigating pathways that repair broken chromosomes. Annu Rev Genet 50: 1-28. doi: 10.1146/annurevgenet-120215-035043

72. Walker JR, Corpina RA, Goldberg J (2001). Structure of the Ku heterodimer bound to DNA and its implications for double-strand break repair. Nature 412(6847): 607-614. doi: 10.1038/35088000

73. Clerici M, Mantiero D, Guerini I, Lucchini G, Longhese MP (2008). The Yku70-Yku80 complex contributes to regulate double-strand break processing and checkpoint activation during the cell cycle. EMBO $\operatorname{Rep} 9$ (8): 810-818. doi: 10.1038/embor.2008.121

74. Mimitou EP, Symington LS (2010). Ku prevents Exo1 and Sgs1dependent resection of DNA ends in the absence of a functional MRX complex or Sae2. EMBO J 29(19): 3358-3369. doi: 10.1038/emboj.2010.193

75. Wilson TE, Grawunder U, Lieber MR (1997). Yeast DNA ligase IV mediates non-homologous DNA end joining. Nature 388(6641): 495498. doi: 10.1038/41365

76. Herrmann G, Lindahl T, Schar P (1998). Saccharomyces cerevisiae LIF1: a function involved in DNA double-strand break repair related to mammalian XRCC4. EMBO J 17(14): 4188-4198. doi: 10.1093/emboj/17.14.4188

77. Zhang $Y$, Hefferin ML, Chen L, Shim EY, Tseng HM, Kwon Y, Sung $P$, Lee SE, Tomkinson AE (2007). Role of Dnl4-Lif1 in nonhomologous end-joining repair complex assembly and suppression of homologous recombination. Nat Struct Mol Biol 14(7): 639-646. doi: 10.1038/nsmb1261

78. Wu D, Topper LM, Wilson TE (2008). Recruitment and dissociation of nonhomologous end joining proteins at a DNA double-strand break in Saccharomyces cerevisiae. Genetics 178(3): 1237-1249. doi: 10.1534/genetics.107.083535

79. Kadyk LC, Hartwell LH (1992). Sister chromatids are preferred over homologs as substrates for recombinational repair in Saccharomyces cerevisiae. Genetics 132(2): 387-402. PMID: 1427035

80. Johnson RD, Jasin M (2000). Sister chromatid gene conversion is a prominent double-strand break repair pathway in mammalian cells. EMBO J 19(13): 3398-3407. doi: 10.1093/emboj/19.13.3398

81. Lisby M, Barlow JH, Burgess RC, Rothstein R (2004). Choreography of the DNA damage response: spatiotemporal relationships among checkpoint and repair proteins. Cell 118(6): 699-713. doi: 10.1016/j.cell.2004.08.015

82. Garcia V, Phelps SE, Gray S, Neale MJ (2011). Bidirectional resection of DNA double-strand breaks by Mre11 and Exo1. Nature 479(7372): 241-244. doi: 10.1038/nature10515

83. Balestrini A, Ristic D, Dionne I, Liu XZ, Wyman C, Wellinger RJ, Petrini JH (2013). The Ku heterodimer and the metabolism of single- ended DNA double-strand breaks. Cell Rep 3(6): 2033-2045. doi: 10.1016/j.celrep.2013.05.026

84. Cannavo E, Cejka $P$ (2014). Sae2 promotes dsDNA endonuclease activity within Mre11-Rad50-Xrs2 to resect DNA breaks. Nature 514(7520): 122-125. doi: 10.1038/nature13771

85. Chanut P, Britton S, Coates J, Jackson SP, Calsou P (2016). Coordinated nuclease activities counteract $\mathrm{Ku}$ at single-ended DNA doublestrand breaks. Nat Commun 7: 12889. doi: 10.1038/ncomms12889

86. Reginato G, Cannavo E, Cejka P (2017). Physiological protein blocks direct the Mre11-Rad50-Xrs2 and Sae2 nuclease complex to initiate DNA end resection. Genes Dev 31(23-24): 2325-2330. doi: 10.1101/gad.308254.117

87. Wang W, Daley JM, Kwon Y, Krasner DS, Sung P (2017). Plasticity of the Mre11-Rad50-Xrs2-Sae2 nuclease ensemble in the processing of DNA-bound obstacles. Genes Dev 31(23-24): 2331-2336. doi: 10.1101/gad.307900.117

88. Shim EY, Chung WH, Nicolette ML, Zhang Y, Davis M, Zhu Z, Paull TT, Ira G, Lee SE (2010). Saccharomyces cerevisiae Mre11/Rad50/Xrs2 and $\mathrm{Ku}$ proteins regulate association of Exo1 and Dna2 with DNA breaks. EMBO J 29(19): 3370-3380. doi: 10.1038/emboj.2010.219

89. Zhu Z, Chung WH, Shim EY, Lee SE, Ira G (2008). Sgs1 helicase and two nucleases Dna2 and Exo1 resect DNA double-strand break ends. Cell 134(6): 981-994. doi: 10.1016/j.cell.2008.08.037

90. Mimitou EP, Symington LS (2008). Sae2, Exo1 and Sgs1 collaborate in DNA double-strand break processing. Nature 455(7214): 770-774. doi: $10.1038 /$ nature 07312

91. Myler LR, Gallardo IF, Soniat MM, Deshpande RA, Gonzalez XB, Kim Y, Paull TT, Finkelstein IJ (2017). Single-molecule imaging reveals how Mre11-Rad50-Nbs1 initiates DNA break repair. Mol Cell 67(5): 891-898 e894. doi: 10.1016/j.molcel.2017.08.002

92. Paques F, Haber JE (1999). Multiple pathways of recombination induced by double-strand breaks in Saccharomyces cerevisiae. Microbiol Mol Biol Rev 63(2): 349-404. PMID: 10357855

93. Sung P, Krejci L, Van Komen S, Sehorn MG (2003). Rad51 recombinase and recombination mediators. J Biol Chem 278(44): 42729 42732. doi: 10.1074/jbc.R300027200

94. Huertas $P$ (2010). DNA resection in eukaryotes: deciding how to fix the break. Nat Struct Mol Biol 17(1): 11-16. doi: 10.1038/nsmb.1710

95. Hustedt N, Durocher D (2016). The control of DNA repair by the cell cycle. Nat Cell Biol 19(1): 1-9. doi: 10.1038/ncb3452

96. Ira G, Pellicioli A, Balijja A, Wang X, Fiorani S, Carotenuto W, Liberi G, Bressan D, Wan L, Hollingsworth NM, Haber JE, Foiani M (2004). DNA end resection, homologous recombination and DNA damage checkpoint activation require CDK1. Nature 431(7011): 1011-1017. doi: $10.1038 /$ nature02964

97. Aylon Y, Liefshitz B, Kupiec M (2004). The CDK regulates repair of double-strand breaks by homologous recombination during the cell cycle. EMBO J 23(24): 4868-4875. doi: 10.1038/sj.emboj.7600469

98. Huertas P, Cortes-Ledesma F, Sartori AA, Aguilera A, Jackson SP (2008). CDK targets Sae2 to control DNA-end resection and homologous recombination. Nature 455(7213): 689-692. doi: 10.1038/nature07215

99. Chen X, Niu H, Chung WH, Zhu Z, Papusha A, Shim EY, Lee SE, Sung $P$, Ira $G$ (2011). Cell cycle regulation of DNA double-strand break end resection by Cdk1-dependent Dna2 phosphorylation. Nat Struct Mol Biol 18(9): 1015-1019. doi: 10.1038/nsmb.2105

100. Ferrari M, Dibitetto D, De Gregorio G, Eapen VV, Rawal CC, Lazzaro F, Tsabar M, Marini F, Haber JE, Pellicioli A (2015). Functional interplay between the 53BP1-ortholog Rad9 and the Mre11 complex regu- 
lates resection, end-tethering and repair of a double-strand break. PLoS Genet 11(1): e1004928. doi: 10.1371/journal.pgen.1004928

101. Chen X, Niu H, Yu Y, Wang J, Zhu S, Zhou J, Papusha A, Cui D, Pan $X$, Kwon $Y$, Sung $P$, Ira G (2016). Enrichment of Cdk1-cyclins at DNA double-strand breaks stimulates Fun30 phosphorylation and DNA end resection. Nucleic Acids Res 44(6): 2742-2753. doi: 10.1093/nar/gkv1544

102. Yu X, Chen J (2004). DNA damage-induced cell cycle checkpoint control requires CtIP, a phosphorylation-dependent binding partner of BRCA1 C-terminal domains. Mol Cell Biol 24(21): 9478-9486. doi: 10.1128/MCB.24.21.9478-9486.2004

103. Chen L, Nievera CJ, Lee AY, Wu X (2008). Cell cycle-dependent complex formation of BRCA1.CtIP.MRN is important for DNA doublestrand break repair. J Biol Chem 283(12): 7713-7720. doi: 10.1074/jbc.M710245200

104. Yun $M H$, Hiom K (2009). CtIP-BRCA1 modulates the choice of DNA double-strand break repair pathway throughout the cell cycle. Nature 459(7245): 460-463. doi: 10.1038/nature07955

105. Iwabuchi K, Bartel PL, Li B, Marraccino R, Fields S (1994). Two cellular proteins that bind to wild-type but not mutant p53. Proc Natl Acad Sci USA 91(13): 6098-6102. PMID: 8016121

106. Zimmermann $M$, de Lange $T$ (2014). 53BP1: pro choice in DNA repair. Trends Cell Biol 24(2): 108-117. doi: 10.1016/j.tcb.2013.09.003

107. Mochan TA, Venere M, DiTullio RA, Jr., Halazonetis TD (2004). 53BP1, an activator of ATM in response to DNA damage. DNA Repair (Amst) 3(8-9): 945-952. doi: 10.1016/j.dnarep.2004.03.017

108. Anderson L, Henderson C, Adachi Y (2001). Phosphorylation and rapid relocalization of 53BP1 to nuclear foci upon DNA damage. Mol Cell Biol 21(5): 1719-1729. doi: 10.1128/MCB.21.5.1719-1729.2001

109. Rappold I, Iwabuchi K, Date T, Chen J (2001). Tumor suppressor p53 binding protein 1 (53BP1) is involved in DNA damage-signaling pathways. J Cell Biol 153(3): 613-620. doi: 10.1083/jcb.153.3.613

110. Xia Z, Morales JC, Dunphy WG, Carpenter PB (2001). Negative cell cycle regulation and DNA damage-inducible phosphorylation of the BRCT protein 53BP1. J Biol Chem 276(4): 2708-2718. doi: 10.1074/jbc.M007665200

111. Bothmer A, Robbiani DF, Di Virgilio M, Bunting SF, Klein IA, Feldhahn N, Barlow J, Chen HT, Bosque D, Callen E, Nussenzweig A, Nussenzweig MC (2011). Regulation of DNA end joining, resection, and immunoglobulin class switch recombination by 53BP1. Mol Cell 42(3): 319-329. doi: 10.1016/j.molcel.2011.03.019

112. Harding SM, Bristow RG (2012). Discordance between phosphorylation and recruitment of 53BP1 in response to DNA doublestrand breaks. Cell Cycle 11(7): 1432-1444. doi: 10.4161/cc.19824

113. Chapman JR, Barral P, Vannier JB, Borel V, Steger M, Tomas-Loba A, Sartori AA, Adams IR, Batista FD, Boulton SJ (2013). RIF1 is essential for 53BP1-dependent nonhomologous end joining and suppression of DNA double-strand break resection. Mol Cell 49(5): 858-871. doi: 10.1016/j.molcel.2013.01.002

114. Callen E, Di Virgilio M, Kruhlak MJ, Nieto-Soler M, Wong N, Chen HT, Faryabi RB, Polato F, Santos M, Starnes LM, Wesemann DR, Lee JE, Tubbs A, Sleckman BP, Daniel JA, Ge K, Alt FW, Fernandez-Capetillo O, Nussenzweig MC, Nussenzweig A (2013). 53BP1 mediates productive and mutagenic DNA repair through distinct phosphoprotein interactions. Cell 153(6): 1266-1280. doi: 10.1016/j.cell.2013.05.023

115. Di Virgilio $M$, Callen $E$, Yamane A, Zhang W, Jankovic $M$, Gitlin AD, Feldhahn N, Resch W, Oliveira TY, Chait BT, Nussenzweig A, Casellas R, Robbiani DF, Nussenzweig MC (2013). Rif1 prevents resection of DNA breaks and promotes immunoglobulin class switching. Science 339(6120): 711-715. doi: 10.1126/science.1230624
116. Escribano-Diaz $C$, Orthwein A, Fradet-Turcotte $A$, Xing $M$, Young JT, Tkac J, Cook MA, Rosebrock AP, Munro M, Canny MD, Xu D, Durocher $D$ (2013). A cell cycle-dependent regulatory circuit composed of 53BP1-RIF1 and BRCA1-CtIP controls DNA repair pathway choice. Mol Cell 49(5): 872-883. doi: 10.1016/j.molcel.2013.01.001

117. Zimmermann M, Lottersberger F, Buonomo SB, Sfeir A, de Lange $T$ (2013). 53BP1 regulates DSB repair using Rif1 to control 5 ' end resection. Science 339(6120): 700-704. doi: 10.1126/science.1231573

118. Panier S, Boulton SJ (2014). Double-strand break repair: 53BP1 comes into focus. Nat Rev Mol Cell Biol 15(1): 7-18. doi: $10.1038 / \mathrm{nrm} 3719$

119. Pei H, Zhang L, Luo K, Qin Y, Chesi M, Fei F, Bergsagel PL, Wang L, You Z, Lou Z (2011). MMSET regulates histone H4K20 methylation and 53BP1 accumulation at DNA damage sites. Nature 470(7332): 124128. doi: $10.1038 /$ nature09658

120. Fradet-Turcotte A, Canny MD, Escribano-Diaz C, Orthwein A, Leung CC, Huang H, Landry MC, Kitevski-LeBlanc J, Noordermeer SM, Sicheri F, Durocher D (2013). 53BP1 is a reader of the DNA-damageinduced H2A Lys 15 ubiquitin mark. Nature 499(7456): 50-54. doi: $10.1038 /$ nature 12318

121. Wilson MD, Benlekbir S, Fradet-Turcotte A, Sherker A, Julien JP, McEwan A, Noordermeer SM, Sicheri F, Rubinstein JL, Durocher D (2016). The structural basis of modified nucleosome recognition by 53BP1. Nature 536(7614): 100-103. doi: 10.1038/nature18951

122. Baldock RA, Day M, Wilkinson OJ, Cloney R, Jeggo PA, Oliver AW, Watts FZ, Pearl LH (2015). ATM localization and heterochromatin repair depend on direct interaction of the 53BP1-BRCT2 domain with $\gamma$ H2AX. Cell Rep 13(10): 2081-2089. doi: 10.1016/j.celrep.2015.10.074

123. Saredi G, Huang H, Hammond CM, Alabert C, Bekker-Jensen S, Forne I, Reveron-Gomez N, Foster BM, Mlejnkova L, Bartke T, Cejka P, Mailand N, Imhof A, Patel DJ, Groth A (2016). H4K20me0 marks postreplicative chromatin and recruits the TONSL-MMS22L DNA repair complex. Nature 534(7609): 714-718. doi: 10.1038/nature18312

124. Pellegrino S, Michelena J, Teloni F, Imhof R, Altmeyer M (2017). Replication-coupled dilution of H4K20me2 guides 53BP1 to prereplicative chromatin. Cell Rep 19(9): 1819-1831. doi: 10.1016/j.celrep.2017.05.016

125. Acs K, Luijsterburg MS, Ackermann L, Salomons FA, Hoppe T, Dantuma NP (2011). The AAA-ATPase VCP/p97 promotes 53BP1 recruitment by removing L3MBTL1 from DNA double-strand breaks. Nat Struct Mol Biol 18(12): 1345-1350. doi: 10.1038/nsmb.2188

126. Mallette FA, Mattiroli F, Cui G, Young LC, Hendzel MJ, Mer G, Sixma TK, Richard S (2012). RNF8- and RNF168-dependent degradation of KDM4A/JMJD2A triggers 53BP1 recruitment to DNA damage sites. EMBO J 31(8): 1865-1878. doi: 10.1038/emboj.2012.47

127. Drane $P$, Brault ME, Cui G, Meghani K, Chaubey S, Detappe A, Parnandi N, He Y, Zheng XF, Botuyan MV, Kalousi A, Yewdell WT, Munch C, Harper JW, Chaudhuri J, Soutoglou E, Mer G, Chowdhury D (2017). TIRR regulates 53BP1 by masking its histone methyl-lysine binding function. Nature 543(7644): 211-216. doi: $10.1038 /$ nature21358

128. Bohgaki M, Bohgaki T, El Ghamrasni S, Srikumar T, Maire G, Panier S, Fradet-Turcotte A, Stewart GS, Raught B, Hakem A, Hakem R (2013). RNF168 ubiquitylates 53BP1 and controls its response to DNA double-strand breaks. Proc Natl Acad Sci USA 110(52): 20982-20987. doi: $10.1073 /$ pnas.1320302111

129. Boisvert FM, Rhie A, Richard S, Doherty AJ (2005). The GAR motif of 53BP1 is arginine methylated by PRMT1 and is necessary for 53BP1 DNA binding activity. Cell Cycle 4(12): 1834-1841. doi: 10.4161/cc.4.12.2250 
130. Orthwein A, Fradet-Turcotte A, Noordermeer SM, Canny MD, Brun CM, Strecker J, Escribano-Diaz C, Durocher D (2014). Mitosis inhibits DNA double-strand break repair to guard against telomere fusions. Science 344(6180): 189-193. doi: 10.1126/science.1248024

131. Lee DH, Acharya SS, Kwon M, Drane P, Guan Y, Adelmant G, Kalev $P$, Shah J, Pellman D, Marto JA, Chowdhury D (2014). Dephosphorylation enables the recruitment of 53BP1 to double-strand DNA breaks. Mol Cell 54(3): 512-525. doi: 10.1016/j.molcel.2014.03.020

132. Guo X, Bai Y, Zhao M, Zhou M, Shen Q, Yun $\mathrm{CH}$, Zhang $\mathrm{H}$, Zhu WG, Wang J (2017). Acetylation of 53BP1 dictates the DNA double strand break repair pathway. Nucleic Acids Res 46(2): 689-703. doi: 10.1093/nar/gkx1208

133. Huertas $P$, Jackson SP (2009). Human CtIP mediates cell cycle control of DNA end resection and double strand break repair. J Biol Chem 284(14): 9558-9565. doi: 10.1074/jbc.M808906200

134. Steger M, Murina O, Huhn D, Ferretti LP, Walser R, Hanggi $K$, Lafranchi L, Neugebauer C, Paliwal S, Janscak P, Gerrits B, Del Sal G, Zerbe O, Sartori AA (2013). Prolyl isomerase PIN1 regulates DNA double-strand break repair by counteracting DNA end resection. Mol Cell 50(3): 333-343. doi: 10.1016/j.molcel.2013.03.023

135. Wang $H$, Shi LZ, Wong CC, Han X, Hwang PY, Truong LN, Zhu Q, Shao Z, Chen DJ, Berns MW, Yates JR, 3rd, Chen L, Wu X (2013). The interaction of CtIP and Nbs1 connects CDK and ATM to regulate HRmediated double-strand break repair. PLoS Genet 9(2): e1003277. doi: 10.1371/journal.pgen.1003277

136. Densham RM, Garvin AJ, Stone HR, Strachan J, Baldock RA, DazaMartin M, Fletcher A, Blair-Reid S, Beesley J, Johal B, Pearl LH, Neely R, Keep NH, Watts FZ, Morris JR (2016). Human BRCA1-BARD1 ubiquitin ligase activity counteracts chromatin barriers to DNA resection. Nat Struct Mol Biol 23(7): 647-655. doi: 10.1038/nsmb.3236

137. Zhang $H$, Liu $H$, Chen $Y$, Yang $X$, Wang $P$, Liu $T$, Deng $M$, Qin $B$, Correia C, Lee S, Kim J, Sparks M, Nair AA, Evans DL, Kalari KR, Zhang P, Wang L, You Z, Kaufmann SH, Lou Z, Pei H (2016). A cell cycledependent BRCA1-UHRF1 cascade regulates DNA double-strand break repair pathway choice. Nat Commun 7: 10201. doi: 10.1038/ncomms10201

138 Nimonkar AV, Ozsoy AZ, Genschel J, Modrich P, Kowalczykowski SC (2008). Human exonuclease 1 and BLM helicase interact to resect DNA and initiate DNA repair. Proc Natl Acad Sci USA 105(44): 1690616911. doi: 10.1073/pnas.0809380105

139. Tomimatsu N, Mukherjee B, Catherine Hardebeck M, Ilcheva M, Vanessa Camacho C, Louise Harris J, Porteus M, Llorente B, Khanna KK, Burma S (2014). Phosphorylation of EXO1 by CDKs 1 and 2 regulates DNA end resection and repair pathway choice. Nat Commun 5 : 3561. doi: 10.1038/ncomms4561

140. Nimonkar AV, Genschel J, Kinoshita E, Polaczek P, Campbell JL, Wyman C, Modrich P, Kowalczykowski SC (2011). BLM-DNA2-RPAMRN and EXO1-BLM-RPA-MRN constitute two DNA end resection machineries for human DNA break repair. Genes Dev 25(4): 350-362. doi: 10.1101/gad.2003811

141. Daley JM, Chiba T, Xue X, Niu H, Sung P (2014). Multifaceted role of the Topo IIlalpha-RMI1-RMI2 complex and DNA2 in the BLMdependent pathway of DNA break end resection. Nucleic Acids Res 42(17): 11083-11091. doi: 10.1093/nar/gku803

142. Sturzenegger A, Burdova K, Kanagaraj R, Levikova M, Pinto $C$, Cejka P, Janscak P (2014). DNA2 cooperates with the WRN and BLM RecQ helicases to mediate long-range DNA end resection in human cells. J Biol Chem 289(39): 27314-27326. doi: 10.1074/jbc.M114.578823

143. Boersma V, Moatti N, Segura-Bayona S, Peuscher $M H$, van der Torre J, Wevers BA, Orthwein A, Durocher D, Jacobs JJL (2015).
MAD2L2 controls DNA repair at telomeres and DNA breaks by inhibiting $5^{\prime}$ end resection. Nature 521(7553): 537-540. doi: $10.1038 /$ nature 14216

144. Martina M, Bonetti D, Villa M, Lucchini G, Longhese MP (2014). Saccharomyces cerevisiae Rif1 cooperates with MRX-Sae2 in promoting DNA-end resection. EMBO Rep 15(6): 695-704. doi: 10.1002/embr.201338338

145. Lazzaro F, Sapountzi V, Granata M, Pellicioli A, Vaze M, Haber JE, Plevani $P$, Lydall D, Muzi-Falconi M (2008). Histone methyltransferase Dot1 and Rad9 inhibit single-stranded DNA accumulation at DSBs and uncapped telomeres. EMBO J 27(10): 1502-1512. doi: 10.1038/emboj.2008.81

146. Trovesi C, Falcettoni M, Lucchini G, Clerici M, Longhese MP (2011). Distinct Cdk1 requirements during single-strand annealing, noncrossover, and crossover recombination. PLoS Genet 7 (8) e1002263. doi: 10.1371/journal.pgen.1002263

147. Ira G, Nussenzweig A (2014). A new Riff: Rif1 eats its cake and has it too. EMBO Rep 15(6): 622-624. doi: 10.1002/embr.201438825

148. Moore JK, Haber JE (1996). Cell cycle and genetic requirements of two pathways of nonhomologous end-joining repair of double-strand breaks in Saccharomyces cerevisiae. Mol Cell Biol 16(5): 2164-2173. doi: 10.1128/MCB.16.5.2164

149. Lee SE, Paques F, Sylvan J, Haber JE (1999). Role of yeast SIR genes and mating type in directing DNA double-strand breaks to homologous and non-homologous repair paths. Curr Biol 9(14): 767-770. doi: 10.1016/S0960-9822(99)80339-X

150. Wysocki R, Javaheri A, Allard S, Sha F, Cote J, Kron SJ (2005). Role of Dot1-dependent histone H3 methylation in $\mathrm{G} 1$ and S phase DNA damage checkpoint functions of Rad9. Mol Cell Biol 25(19): 84308443. doi: 10.1128/MCB.25.19.8430-8443.2005

151. Grenon M, Costelloe T, Jimeno S, O'Shaughnessy A, Fitzgerald J, Zgheib O, Degerth L, Lowndes NF (2007). Docking onto chromatin via the Saccharomyces cerevisiae Rad9 Tudor domain. Yeast 24(2): 105119. doi: 10.1002/yea.1441

152. Toh GW, O'Shaughnessy AM, Jimeno S, Dobbie IM, Grenon M, Maffini S, O'Rorke A, Lowndes NF (2006). Histone H2A phosphorylation and $\mathrm{H} 3$ methylation are required for a novel Rad9 DSB repair function following checkpoint activation. DNA Repair (Amst) 5(6): 693-703. doi: 10.1016/j.dnarep.2006.03.005

153. Hammet A, Magill C, Heierhorst J, Jackson SP (2007). Rad9 BRCT domain interaction with phosphorylated $\mathrm{H} 2 \mathrm{AX}$ regulates the $\mathrm{G} 1$ checkpoint in budding yeast. EMBO Rep 8(9): 851-857. doi: 10.1038/sj.embor.7401036

154. Yoshimura SH, Hirano T (2016). HEAT repeats - versatile arrays of amphiphilic helices working in crowded environments? J Cell Sci 129(21): 3963-3970. doi: 10.1242/jcs.185710

155. Mishra K, Shore D (1999). Yeast Ku protein plays a direct role in telomeric silencing and counteracts inhibition by Rif proteins. Curr Biol 9(19): 1123-1126. doi: 10.1016/S0960-9822(99)80483-7

156. Smith CD, Smith DL, DeRisi JL, Blackburn EH (2003). Telomeric protein distributions and remodeling through the cell cycle in Saccharomyces cerevisiae. Mol Biol Cell 14(2): 556-570. doi: 10.1091/mbc.E02-08-0457

157. Park S, Patterson EE, Cobb J, Audhya A, Gartenberg MR, Fox CA (2011). Palmitoylation controls the dynamics of budding-yeast heterochromatin via the telomere-binding protein Rif1. Proc Natl Acad Sci USA 108(35): 14572-14577. doi: 10.1073/pnas.1105262108

158. Kalousi A, Soutoglou E (2016). Nuclear compartmentalization of DNA repair. Curr Opin Genet Dev 37: 148-157. doi: 10.1016/j.gde.2016.05.013 
159. Marnef A, Legube G (2017). Organizing DNA repair in the nucleus: DSBs hit the road. Curr Opin Cell Biol 46: 1-8. doi: 10.1016/j.ceb.2016.12.003

160. Bressan DA, Baxter BK, Petrini JH (1999). The Mre11-Rad50-Xrs2 protein complex facilitates homologous recombination-based doublestrand break repair in Saccharomyces cerevisiae. Mol Cell Biol 19(11) 7681-7687. doi: 10.1128/MCB.19.11.7681

161. Chen L, Trujillo K, Ramos W, Sung P, Tomkinson AE (2001). Promotion of Dnl4-catalyzed DNA end-joining by the Rad50/Mre11/Xrs2 and Hdf1/Hdf2 complexes. Mol Cell 8(5): 1105-1115. PMID: 11741545

162. Lobachev K, Vitriol E, Stemple J, Resnick MA, Bloom K (2004). Chromosome fragmentation after induction of a double-strand break is an active process prevented by the RMX repair complex. Curr Biol 14(23): 2107-2112. doi: 10.1016/j.cub.2004.11.051

163. Wiltzius JJ, Hohl M, Fleming JC, Petrini JH (2005). The Rad50 hook domain is a critical determinant of Mre11 complex functions. Nat Struct Mol Biol 12(5): 403-407. doi: 10.1038/nsmb928

164. Hohl M, Kwon Y, Galvan SM, Xue X, Tous C, Aguilera A, Sung P, Petrini JH (2011). The Rad50 coiled-coil domain is indispensable for Mre11 complex functions. Nat Struct Mol Biol 18(10): 1124-1131. doi: $10.1038 /$ nsmb.2116

165. Seeber A, Hegnauer AM, Hustedt N, Deshpande I, Poli J, Eglinger J, Pasero P, Gut H, Shinohara M, Hopfner KP, Shimada K, Gasser SM (2016). RPA mediates recruitment of MRX to forks and double-strand breaks to hold sister chromatids together. Mol Cell 64(5): 951-966. doi: 10.1016/j.molcel.2016.10.032

166. Seifert FU, Lammens K, Stoehr G, Kessler B, Hopfner KP (2016). Structural mechanism of ATP-dependent DNA binding and DNA end bridging by eukaryotic Rad50. EMBO J 35(7): 759-772. doi: 10.15252/embj.201592934

167. de Jager $M$, van Noort J, van Gent DC, Dekker C, Kanaar R, Wyman C (2001). Human Rad50/Mre11 is a flexible complex that can tether DNA ends. Mol Cell 8(5): 1129-1135. doi: 10.1016/S10972765(01)00381-1

168. de Jager M, Wyman C, van Gent DC, Kanaar R (2002). DNA endbinding specificity of human Rad50/Mre11 is influenced by ATP. Nucleic Acids Res 30(20): 4425-4431. PMID: 12384589
169. Hopfner KP, Craig L, Moncalian G, Zinkel RA, Usui T, Owen BA, Karcher A, Henderson B, Bodmer JL, McMurray CT, Carney JP, Petrini $\mathrm{JH}$, Tainer JA (2002). The Rad50 zinc-hook is a structure joining Mre11 complexes in DNA recombination and repair. Nature 418(6897): 562566. doi: 10.1038/nature00922

170. Lafrance-Vanasse J, Williams GJ, Tainer JA (2015). Envisioning the dynamics and flexibility of Mre11-Rad50-Nbs1 complex to decipher its roles in DNA replication and repair. Prog Biophys Mol Biol 117(2-3): 182-193. doi: 10.1016/j.pbiomolbio.2014.12.004

171. Griffith JD, Comeau L, Rosenfield S, Stansel RM, Bianchi A, Moss $\mathrm{H}$, de Lange $\mathrm{T}$ (1999). Mammalian telomeres end in a large duplex loop. Cell 97(4): 503-514. doi: 10.1016/S0092-8674(00)80760-6

172. Stansel RM, de Lange T, Griffith JD (2001). T-loop assembly in vitro involves binding of TRF2 near the 3' telomeric overhang. EMBO J 20(19): 5532-5540. doi: 10.1093/emboj/20.19.5532

173. Strahl-Bolsinger S, Hecht A, Luo K, Grunstein M (1997). SIR2 and SIR4 interactions differ in core and extended telomeric heterochromatin in yeast. Genes Dev 11(1): 83-93. doi: 10.1101/gad.11.1.83

174. de Bruin D, Kantrow SM, Liberatore RA, Zakian VA (2000). Telomere folding is required for the stable maintenance of telomere position effects in yeast. Mol Cell Biol 20: 7991-8000. doi: 10.1128/MCB.20.21.7991-8000.2000

175. de Bruin D, Zaman Z, Liberatore RA, Ptashne M (2001). Telomere looping permits gene activation by a downstream UAS in yeast. Nature 409(6816): 109-113. doi: 10.1038/35051119

176. Tomaska L, Willcox S, Slezakova J, Nosek J, Griffith JD (2004). Taz1 binding to a fission yeast model telomere: formation of telomeric loops and higher order structures. J Biol Chem 279(49): 50764-50772. doi: 10.1074/jbc.M409790200

177. Poschke $H$, Dees $M$, Chang $M$, Amberkar S, Kaderali L, Rothstein $\mathrm{R}$, Luke B (2012). Rif2 promotes a telomere fold-back structure through Rpd3L recruitment in budding yeast. PLoS Genet 8(9): e1002960. doi: 10.1371/journal.pgen.1002960

178. Mattarocci S, Hafner L, Lezaja A, Shyian M, Shore D (2016). Rif1: a conserved regulator of DNA replication and repair hijacked by telomeres in yeasts. Front Genet 7: 45. doi: 10.3389/fgene.2016.00045 